UNIVERSIDADE DE BRASÍLIA INSTITUTO DE RELAÇÕES INTERNACIONAIS

LÍVIA CASTELO BRANCO MARCOS MILANEZ

\title{
AMÉRICA DO SUL - COMUNIDADE IDENTITÁRIA, COMPLEXO DE SEGURANÇA
}




\title{
AMÉRICA DO SUL - COMUNIDADE IDENTITÁRIA, COMPLEXO DE SEGURANÇA
}

\author{
Monografia apresentada ao Instituto de \\ Relações Internacionais da Universidade de \\ Brasília como requisito parcial para obtenção \\ do título de Bacharel em Relações \\ Internacionais.
}

Banca Examinadora

Prof. Dr. Alcides Costa Vaz (Orientador)

Prof $^{a}$ Dr $^{\mathrm{a}}$ Albene Míriam Menezes - Departamento de História/ UnB

Prof. Dr. Eiiti Sato - Instituto de Relações Internacionais/ UnB 


\title{
AMÉRICA DO SUL - COMUNIDADE IDENTITÁRIA, COMPLEXO DE SEGURANÇA
}

\author{
Banca Examinadora
}

Prof. Dr. Alcides Costa Vaz (Orientador) - Instituto de Relações Internacionais/ UnB

Prof $^{a}$ Dr $^{\mathrm{a}}$ Albene Míriam Menezes - Departamento de História/ UnB

Prof. Dr. Eiiti Sato - Instituto de Relações Internacionais/ UnB

\author{
BRASÍLIA
}

JUNHO DE 2008 
Dedico este trabalho a meus pais e irmãos, cujo apoio sempre tive em todos os meus empreendimentos. 


\section{AGRADECIMENTOS}

Este trabalho foi possível graças à motivação que me transmitiram os verdadeiros mestres com quem tive a oportunidade de aprender durante minha graduação. Esses homens e mulheres dedicam sua vida ao amor ao conhecimento e acreditam no potencial de seus alunos, jamais duvidando de quão longe estes possam ir e respeitando seu pensamento crítico e autônomo.

Tais mestres sabem que a bons professores correspondem bons alunos, por isso sentem-se realizados ao despertarem, em seus ensinamentos, a centelha investigativa e o interesse pela pesquisa, cujas conclusões e resultados são valorizados não por sua perfeição, mas pelo esforço honesto em retribuir conhecimento com conhecimento.

Àqueles que foram meus verdadeiros professores dedico este trabalho. 


\section{RESUMO}

Este trabalho discorre sobre os conceitos de comunidade de segurança e complexo regional de segurança, retomando suas origens, tipologias, aplicações e arcabouços teóricos.

A seguir, a autora sugerirá que o conceito de comunidade de segurança seja substituído pelo conceito de comunidade identitária para o caso da América do Sul, mantendo o conceito de complexo regional de segurança e justificando essa opção. Por último, serão apresentadas duas análises dos subcomplexos de segurança sul-americanos tradicionais (o Cone Sul e o subcomplexo Andino), com os principais temas securitizados e a hipótese de um novo subcomplexo no entorno amazônico.

Palavras-chave: América do Sul. Comunidade. Segurança. 


\section{LISTA DE ILUSTRAÇÕES}

FIGURA - Diagrama do conceito de comunidade de segurança sofisticado por Adler e

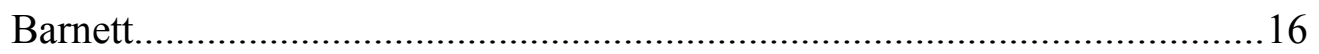




\section{LISTA DE TABELAS}

TABELA 1 - Indicadores da existência de comunidades de segurança frouxas e

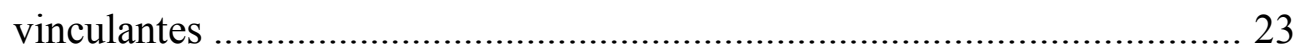

TABELA 2 - A constelação de segurança ou os quatro níveis de análise na TCSR 33

TABELA 3 - As variáveis que compõem um CSR 34 


\section{SUMÁRIO}

INTRODUÇÃO 10

PARTE I - RETOMADA DOS CONCEITOS DE COMUNIDADE DE SEGURANÇA E COMPLEXO REGIONAL DE SEGURANÇA

Capítulo 1 - O Conceito de Comunidade de Segurança

$1.1 \mathrm{O}$ conceito de comunidade de segurança e tipologia ............................................ 13

1.2 Estágios de desenvolvimento das comunidades de segurança ............................... 19

1.3 A América do Sul percebida como uma comunidade identitária - práticas discursivas e cooperativas

Capítulo 2 - O Conceito de Complexo de Segurança Regional

$2.1 O$ conceito de complexo de segurança regional, inter-relação de níveis de análise (constelação de segurança), variáveis e tipologia 29

2.2 A América do Sul percebida como um complexo de segurança regional 40

2.3 Opção pelo conceito de complexo de segurança regional para a América do Sul 45

PARTE II - OS SUBCOMPLEXOS DE SEGURANÇA TRADICIONAIS NA AMÉRICA DO SUL

Capítulo 3 - O Subcomplexo do Cone Sul

3.1 Mercosul - o principal empreendimento cooperativo no Cone Sul 49

3.1.1 Uma união aduaneira e zona de livre comércio 49

3.1.2 Mercosul - além do comércio e da economia 51

3.2 Brasil - hegemonia estabilizadora? 53

Capítulo 4 - O Subcomplexo Andino

4.1 O Pacto Andino ou Comunidade Andina 59

4.1.1 Colômbia - foco do spill-over de tensões na região

4.2 Organização para o Tratado de Cooperação Amazônica (OTCA) - perspectiva de um subcomplexo amazônico? 66

CONCLUSÃO 69

REFERÊNCIAS 71 


\section{INTRODUÇÃO}

Este trabalho realiza uma avaliação dos conceitos de comunidade de segurança e complexo regional de segurança aplicando-os à América do Sul atual a fim de entender os padrões de cooperação no continente, institucionalizados sob duas importantes organizações regionais cujo propósito é integrar econômica e comercialmente os países sul-americanos a fim de torná-los mais competitivos no mundo globalizado e regionalizante: o Mercosul e a Comunidade Andina.

A cooperação comercial tem se mostrado um projeto de longo prazo e as instituições sob as quais ela se dá têm expandido sua esfera de atuação a fim de abrangerem diversos setores da vida política e social dos países envolvidos, o que indica um objetivo de integração do continente sob valores compartilhados e uma identidade comum: a sul-americana.

A ligação entre cooperação comercial sob o Mercosul e a Comunidade Andina e os temas de segurança dá-se dentro do referencial teórico de alargamento do conceito de segurança realizado por Buzan, Wæver e de Wilde (1998), segundo o qual segurança abrange, além dos temas político-militares, o meio ambiente, a economia e a sociedade. Segurança, para esses autores,

is the move that takes politics beyond the established rules of the game and frames the issue either as a special kind of politics or as above politics. Securitization can thus be seen as a more extreme version of politicization. In theory, any public issue can be located on the spectrum ranging from nonpoliticized (meaning the state does not deal with it and is not in any other way made an issue of public debate and decision) through politicized (meaning the issue is part of public policy, requiring government decision and resource allocation or, more rarely, some other form of communal governance) to securitized (meaning the issue is presented as an existential threat, requiring emergency measures and justifying actions outside the normal bounds of political procedure. (Buzan, Wæver e de Wilde, 1998, pp. 23-24)

Na América do Sul, as duas principais dimensões securitizadas desde a década de 1990 são, como será justificado ao longo do trabalho, a política e a economia. Para o primeiro caso, as instituições regionais buscam apresentar-se como mecanismos de continuidade e transparência, ao mesmo tempo em que devem atuar protegendo a democracia e a estabilidade dos governos. No segundo caso, o objetivo dos organismos multilaterais da região deve ser 
conferir maior poder de barganha e competitividade na economia globalizada e setorizada em blocos econômicos regionais.

Os novos temas de segurança para a região relacionam-se especialmente a ameaças transfronteiriças, como no caso da segurança ambiental, que deve ser garantida com o combate a várias formas de ilícitos transnacionais (como as várias modalidades de contrabando, o narcotráfico) e, em se tratando de segurança societal, referem-se a ameaças a vários grupos indígenas cujos modos de vida e identidades culturais têm sido ameaçados pela agressão a seus locais de origem, caso dos povos amazônicos, ou pelo desvio de finalidade de produtos tradicionais, como a coca produzida pelos cocaleros bolivianos; ainda, a segurança societal envolve o crime organizado, bem como os problemas de violência urbana e rural.

O debate sobre a construção de uma identidade comum permeia as práticas cooperativas e discursivas no continente sul-americano e será baseado nos conceitos de comunidade da literatura levantada por Adler e Barnett (1998) para a elaboração de seu conceito de comunidade segurança, que, segundo a argumentação deste trabalho, não se manifesta na América do Sul. A perspectiva desta obra é a de que o continente ensaia a construção de uma identidade comum que, eventualmente, levará a um padrão de amizade típico de uma comunidade de segurança, mas esse estágio ainda parece distante e incerto no horizonte histórico.

Por último, será levantada a hipótese, dentro da teoria dos complexos de segurança regional (TCSR) de Buzan e Wæver, de um novo subcomplexo de segurança para a América do Sul, o subcomplexo amazônico, palco dos novos desafios para a segurança no continente. Propõe-se, a exemplo do que será feito com os subcomplexos andino e do Cone Sul, estudar essa nova unidade de análise a partir de uma instituição governamental multilateral. Será escolhida a Organização do Tratado de Cooperação Amazônica por sua proposta ser concentrada na região que corresponde ao subcomplexo e por abranger governos que, em princípio, estariam interessados na segurança (entendida na acepção estendida de Buzan et al.) desse locus.

Após argumentar-se acerca da insuficiência da OTCA para agir como o centro irradiador da securitização no novo subcomplexo, é sugerido que atores diferentes dos Estados podem se mostrar mais presentes na região amazônica, fazendo, assim, com que esse subcomplexo sofra mais com influências externas (ou transnacionais) do que com a dos atores regionais governamentais. 
PARTE I - RETOMADA DOS CONCEITOS DE COMUNIDADE DE SEGURANÇA E COMPLEXO REGIONAL DE SEGURANÇA 


\section{CAPÍTULO 1 - O CONCEITO DE COMUNIDADE DE SEGURANÇA}

\subsection{O Conceito de Comunidade de Segurança e Tipologia}

O conceito de comunidade de segurança é anterior ao de complexo de segurança regional, tendo sido formulado por Richard van Wagenen e, posteriormente, desenvolvido por Karl Deutsch (Deutsch, 1957) durante a Guerra Fria (Herz, s/d, p. 11). O termo indica uma opção analítica contrária ao mainstream dos esforços teóricos do período 1947-1989 (Guerra Fria), pois apresenta uma "discussão sobre regiões onde a guerra seria excluída como opção para as relações entre Estados" (Herz, s/d, p. 12).

Uma comunidade de segurança, para Deutsch, é "um grupo de países integrados dentre os quais uma noção de comunidade desenvolveu-se de forma a proscrever a possibilidade do conflito entre si" (Deutsch apud Herz, s/d, p. 15). Posteriormente, o conceito foi utilizado e ampliado por Adler e Barnett (1998), que o reformularam na forma de comunidade pluralística de segurança, ou seja, "uma região transnacional composta por Estados onde as pessoas mantêm expectativas dependentes de mudança pacífica”(Adler e Barnett apud Schleicher, s/d, p. 6).

Segundo Adler e Barnett, uma comunidade possui três dimensões: (i) a existência de expectativas de reciprocidade, obrigação e responsabilidade no longo prazo; (ii) a existência de múltiplos canais de comunicação entre os atores; (iii) o compartilhamento de significados, valores e identidades (Adler e Barnett, 1998, p. 31).

O conceito de comunidade de segurança, ainda segundo esses autores, tem na sua maior virtude justamente um vício: o conceito cria um vocabulário útil para a epistemologia do tema, mas também carrega consigo outros conceitos difíceis de serem administrados expectativas dependentes de mudança pacífica, comunidade, governança, instituições etc. (Adler e Barnett, 1998, p. 29).

As expectativas dependentes são abordadas tanto por teorias racionalistas (neorealistas e liberal-institucionalistas, que partem da premissa de que os interesses e preferências 
dos atores são dados ${ }^{1}$ ) quanto por teorias sociológicas e construtivistas. Os autores fazem sua opção teórica segundo a abordagem que querem dar para explicar a ausência de guerra e, na definição de expectativas dependentes, optam pelas teorias sociológicas, por julgarem que:

[...] only sociological theories allow for the possibility that interstate interactions
can transform the identities and interests of states and induce dependable
expectations of peacuful change. [...] [T] he sociological approach adopted here
isolates knowledge, learning and the existence of norms that emerge from both
interstate practices and, more fundamentally, transnational forces" (Adler $\mathrm{e}$
Barnett, 1998, p. 34).

Mudanças pacíficas significam ausência de ações de segurança, por parte dos membros da comunidade, que possam ser interpretadas pelos outros membros como ameaças militares direcionadas a estes. As comunidades de segurança podem existir na ausência de laços estratégicos ou alianças formais, mas haverá sempre proibições, tácitas ou formais, ao uso de meios militares para a resolução de disputas.

A formulação do conceito de comunidade, no qual se baseiam os desenvolvimentos das idéias de comunidade de segurança e suas derivações, conta com grandes esforços na Sociologia, como no texto de Charles Tilly ${ }^{2}$ para o trabalho de Adler e Barnett e, também, na Ciência Política, onde Michael Taylor ${ }^{3}$ define comunidade segundo três características. A primeira delas é o compartilhamento de valores, identidades e significados. A seguir, há a multilateralidade nas relações dos membros de uma comunidade, em que as interações se dão de forma direta e em vários domínios. Por último, as comunidades expressam uma reciprocidade que significa um grau de interesse de longo prazo e pode significar também altruísmo. O grau de interesse de longo prazo deriva do conhecimento dos parceiros com quem se interage e o altruísmo pode ser definido como um senso de obrigação e responsabilidade.

Ferdinand Tonnie definiu associação e comunidade afirmando que o que distinguia uma da outra era o agir das associações dentro de interesses próprios, enquanto as comunidades não o fariam ${ }^{4}$. Para Adler e Barnett (1998, p. 32), o critério de ação em interesse

\footnotetext{
${ }^{1}$ Essas abordagens desenvolvem sua argumentação sobre as premissas de que o ator é egoísta e deseja manter sua sobrevivência num estado de natureza hobbesiano (no caso do realismo e do neo-realismo) ou sob o pressuposto de que o ator é racional e maximizador (teorias liberal-intitucionalistas).

2 TILLY, Charles (1998): "International communities, secure or otherwise" In ADLER, Emanuel; BARNETT, Michael (1998). Security Communities... op. cit. Cap. 12, pp. 397-412.

${ }^{3}$ TAYLOR, Michael (1982): Community, Anarchy and Liberty. New York, Cambridge University Press, 1982, pp.25-33.

${ }^{4}$ Trata-se da distinção clássica entre Gemeinschaft e Gesellschaft. Gemeinschaft refere-se a uma comunidade orgânica que envolve laços de tradição e cultura, enquanto Gesellschaft é contratual e
} 
próprio não é o melhor definidor de comunidades e associações, pois membros de comunidades também agem em interesse próprio. Para os autores, um critério adequado para a distinção seria o grau de reciprocidade difusa: nas associações, a reciprocidade é imediata e o grau de difusão da reciprocidade, portanto, menor; nas comunidades, o grau é maior, pois nem todos os interesses seriam imediatos ou issue-based - nas comunidades, ainda, há uma correlação maior entre os interesses individuais dos membros e os interesses coletivos, ou seja, os membros de uma comunidade são mais afetados pelos interesses do grupo, sendo que têm, numa medida maior do que nas associações, os interesses do grupo como interesses individuais.

Diferentes tipos de comunidade estabelecem mecanismos distintos de regulação de conflitos, sendo que algumas comunidades (as comunidades de segurança) regulam seus conflitos a partir da expectativa de mudança pacífica. Todas as comunidades políticas contêm normas para regular a segurança e manter a ordem, mas nem todas garantirão que essa ordem e segurança serão mantidas por meios não violentos. Adler e Barnett mencionam, neste sentido, a possibilidade de existência de comunidades de guerra (1998, p. 34).

As comunidades de segurança podem ser pluralísticas (caso as soberanias das unidades sejam mantidas) ou amalgamadas (caso que em que há a fusão de soberanias, como parece ser o caminho que a União Européia, pelo menos entre os países da Europa Ocidental, pretende seguir).

As comunidades pluralísticas de segurança, objeto principal do interesse de Adler e Barnett, categorizam-se de acordo com o grau de confiança, a natureza e o grau de institucionalização de seu sistema de governança e, por último, quanto a estarem numa anarquia formal ou em vias de transformá-la (Adler e Barnett, 1998, p. 30).

O grau em que essas características se apresentam permite mais duas caracterizações: comunidades de segurança pluralísticas frouxas ou vinculantes ${ }^{5}$.

emerge de um comportamento auto-interessado. Ver TONNIES, Ferdinand (1955): Community and Association. London: Routledge and Kegan Paul.

${ }^{5}$ Ver, no inglês, loosely and tightly coupled pluralistic security communities (Adler e Barnett, 1998, p. 30). Não confundir tightly coupled community (aqui traduzido como comunidade vinculante) com bounded community (que, aqui, não receberá tradução). Outras traduções para loosely and tightly coupled pluralistic security communities seriam comunidades de segurança pluralísticas bem e mal casadas. 


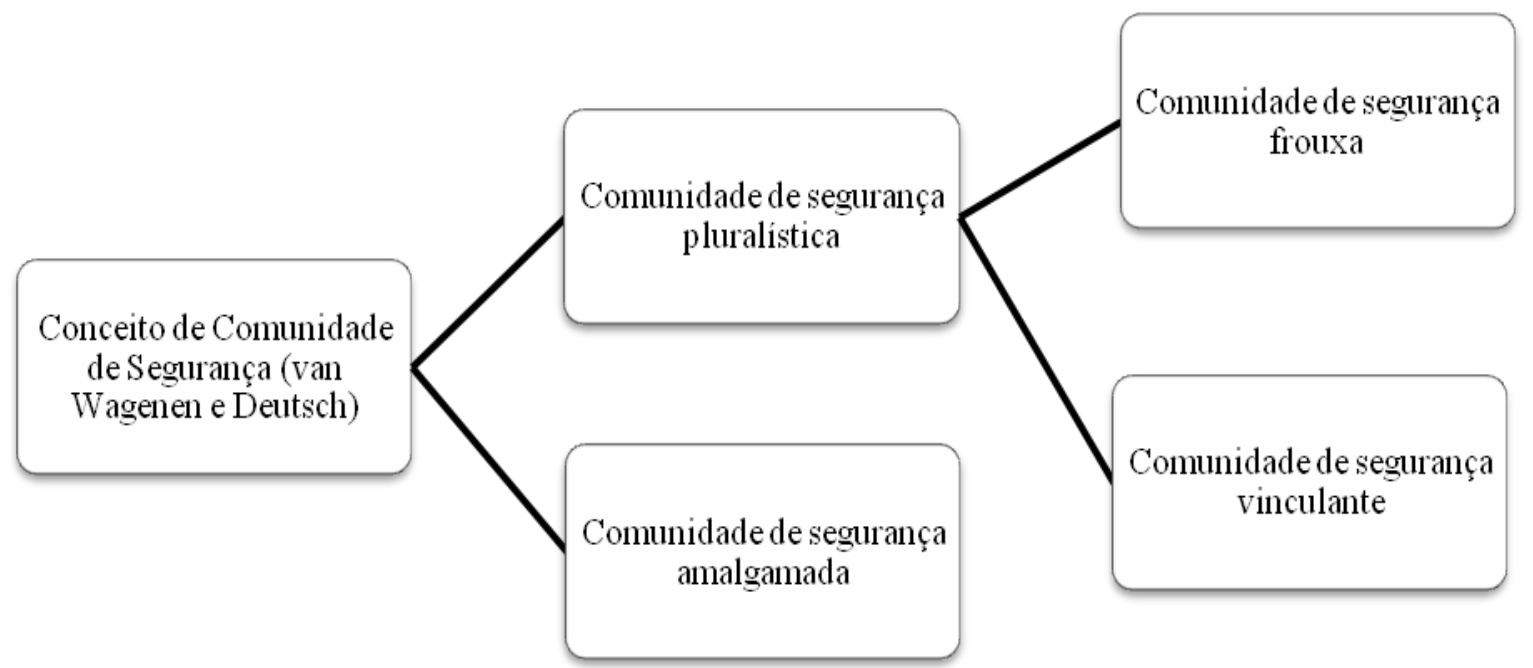

Figura. Diagrama, da autora, do conceito de comunidade de segurança sofisticado por Adler e Barnett.

Graças ao compartilhamento de significados e identidade, os membros das comunidades de segurança frouxas não esperam agressão uns dos outros e praticam autocontenção para também não serem os agressores, mas seguem num grau mínimo as propriedades definidoras de uma comunidade segurança, ou seja, não há ameaças porque não há necessidade de entrar-se em conflito e isso pode estar condicionado a vários fatores particulares a uma comunidade, por exemplo, ausência de conflito decorrente de baixa interação.

Já as comunidades de segurança vinculantes são mais exigentes em relação ao conceito de comunidades pluralísticas de segurança em dois aspectos. O primeiro deles diz respeito a que estas comunidades constroem uma sociedade de "ajuda mútua", ou seja, são estabelecidos arranjos coletivos. Em segundo lugar, estas comunidades possuem um sistema intermediário entre o Estado soberano e um governo regional central. Há um sistema póssoberano dotado de instituições nacionais, transnacionais e supranacionais comuns e alguma modalidade de sistema de segurança coletiva ${ }^{6}$.

O quarto conceito componente da definição de comunidade de segurança, segundo Adler e Barnett, depois dos conceitos de expectativas dependentes, mudanças pacíficas e comunidade, é o conceito de governança. Uma estrutura de governança pode ser concebida como os hábitos e práticas de resolução pacífica dos conflitos mais as normas compartilhadas nas quais esses hábitos e práticas se baseiam (Adler e Barnett, 1998, p. 35). Segundo a clássica definição de Rosenau, que os autores adotam, governança são as atividades

\footnotetext{
${ }^{6}$ RUGGIE, John G. (1993): “Territoriality and Beyond: Problematizing Modernity in International Relations”, International Organization 47, p. 172.
} 
fundamentadas em metas compartilhadas e significados intersubjetivos que podem ou não derivar de responsabilidades formal ou legalmente prescritas e que, não necessariamente, dependem do poder político para superar a desconfiança e alcançar o acordo ${ }^{7}$.

O conceito de governança pode implicar normas vindas de cima e de fora, já que admite responsabilidades formalmente prescritas, talvez por instituições supranacionais, que regularão as atividades dos membros da comunidade. Essa possibilidade gera um questionamento sobre se normas de cima não negariam a formação de uma comunidade, caso esta seja entendida como um locus de interação social cujas normas baseiam-se no compartilhamento de identidade e são definidas pelos membros da comunidade e dentro dela. A resposta a este questionamento é que normas impostas não impossibilitam a formação de uma comunidade (cujas normas, grosso modo, seriam auto-impostas) porque essas normas de cima, ou de fora não são apenas regulatórias (formuladas com o propósito de superar os problemas de ação coletiva advindos das escolhas interdependentes), mas, também, são constitutivas, pois, ao serem formuladas, refletem, em alguma medida, as identidades dos atores, suas auto-percepções e percepções dos outros na comunidade ${ }^{8}$.

Os Estados de uma comunidade de segurança confiarão à sua estrutura de governança não apenas o concerto entre seus comportamentos na esfera internacional, mas também a leitura de seus comportamentos e arranjos domésticos. Isso significa que uma estrutura de governança numa comunidade de segurança estará relacionada tanto às identidades externas dos Estados (e os comportamentos associados a essas identidades) quanto às identidades e práticas internas.

No caso de uma possível comunidade de segurança na América do Sul, observa-se que havia uma crítica constante dos vizinhos do Brasil, sobretudo da Argentina, a uma suposta incoerência entre os discursos brasileiros de afirmação de identidade externa (um Brasil benevolente e favorável a uma integração sul-americana) e as práticas internas de formulação, na política brasileira, de hegemonia no continente.

A soberania, a autoridade e a legitimidade de um Estado são alteradas quando se forma uma estrutura de governança sob uma comunidade de segurança. Essas alterações decorrem de dois fatores. O primeiro consiste em que, quanto mais uma comunidade de

\footnotetext{
7 ROSENAU, James (1992): "Governance, Order and Change in World Politics" In ROSENAU, J.; CZEMPIEL, E. (eds.) Governance without government: Order and Change in World Politics. New York: Cambridge University Press, p. 4.

${ }^{8}$ Distinção entre normas regulatórias e constitutivas em HOLLIS, Martin (1988): The Cunning of Reason. New York: Cambridge University Press, pp. 137-141.
} 
segurança se torna vinculante, mais o Estado aumenta seu escopo de atuação, de acordo com os autores analisados nesta parte do trabalho (Adler e Barnett, 1998, Cap. 2). O segundo fator consiste em que o caráter da soberania, autoridade e legitimidade de um Estado mudam de teor conforme o grau em que ele internaliza e age em conformidade com a estrutura normativa da região (Adler e Barnett, 1998, pp. 36-37). Para estes autores, os Estados agem com mais liberdade no nível da comunidade quanto mais próximos estiverem seus valores e práticas daqueles da comunidade. Essa liberdade, não seria, então, uma liberdade condicionada à comunidade? Isto não seria indicativo de uma diminuição na soberania dos Estados à medida em que as comunidades de segurança tornam-se mais vinculantes?

Acerca do ponto em que o escopo de atuação dos Estados aumenta na proporção em que uma comunidade de segurança se torna vinculada (perspectiva de Adler e Barnett), a leitura da autora é de que esse aumento não implica uma maior soberania, mas apenas significa que o Estado assumirá as funções mais complexas que a interdependência da comunidade demanda. Se, no período anterior ao da comunidade, o Estado provia apenas o bem nacional (Adler e Barnett, 1998, p. 36), o Estado passa, neste novo período, a prover segurança, bem-estar econômico, proteção ambiental, respeito aos direitos humanos etc. Como a execução dessas tarefas se dá sob os valores da comunidade, o Estado não expande sua soberania, mesmo porque tais tarefas ainda podem ser delegadas (num indício de redução de soberania) a instituições transnacionais, interestatais ou supranacionais da comunidade.

Uma dificuldade na operacionalização do conceito de comunidade de segurança está em que ele não comporta os fatores subjacentes a esse trânsito que ocorre no grau de soberania dos Estados em uma comunidade de segurança que se consolida. Entre tais fatores subjacentes estão as alterações nos balanços de poder e polaridades, cuja análise demonstra ser de grande relevância para a explicação do fenômeno da ausência de guerra. O conceito de complexo de segurança regional leva em consideração esses fatores e, por isso, será justificado posteriormente neste trabalho por que ele foi escolhido para a compreensão do caso da América do $\mathrm{Sul}^{9}$.

\footnotetext{
${ }^{9}$ Para Adler e Barnett, as perspectivas realista e institucionalistas neo-liberais são "mal equipadas" (Adler e Barnett, 1998, p. 59) para compreenderem a dimensão comunitária do fenômeno de ausência de guerra. Eles optam, assim, por abordagens construtivistas e sociológicas, admitindo que os estudos de segurança devam ser reformulados sobre novas bases, que admitam a possibilidade de mudança pacífica por meio da construção de identidade entre os povos e não por meio dos esquemas de segurança coletiva e balanço de poder. Ver também, a este respeito, PUCHALA, Donald J. (1981): "Integration Theory and the Study of International Relations" In MERITT, Richard L.; RUSSETT, Bruce M. (eds.) From National Development to Global Community: Essays in Honor of Karl W. Deutsch. London: Allen and Unwin, p. 51.
} 


\subsection{Estágios de desenvolvimento das comunidades de segurança}

Adler e Barnett (1998, p. 29) afirmam que, em um enquadramento analítico, é possível estabelecer-se uma cadeia de fatores (tiers) que levam à emergência de uma comunidade de segurança: (i) os fatores precipitadores, que orientam os Estados a voltarem-se uns para os outros a fim de coordenarem suas políticas; (ii) os elementos estruturais, poder e idéia, por um lado, e, por outro, os elementos processuais, transações, organizações internacionais e aprendizado social; (iii) o desenvolvimento de confiança e formação de identidade coletiva.

Adler e Barnett trabalham apenas com fatores precipitadores endógenos e exógenos, mas a autora acredita que a definição da natureza de um fator como endógeno ou exógeno pode, muitas vezes, ignorar suas múltiplas causalidades. Assim, vários fatores podem ser considerados mistos, por não ser possível determinar a proporção em que suas origens definem-nos como endógenos ou exógenos.

Fatores endógenos podem ser crises econômicas, que levam à percepção de que a cooperação comercial pode ser uma boa alternativa para os problemas internos; podem ser guerras civis, gerando fluxos migratórios que afetam os países vizinhos etc. Fatores exógenos podem ser ameaças externas, como uma potência tentar expandir-se anexando os membros da pré-comunidade. Fatores mistos são aqueles que não podem ser claramente definidos como exógenos ou endógenos: é o caso, por exemplo, das ameaças ambientais transfronteiriças ou do desenvolvimento de novas interpretações da realidade social - idéias que modificam as percepções que os membros da pré-comunidade têm uns dos outros.

Quando os elementos precipitadores levam os membros da potencial comunidade a interagirem com mais freqüência na expectativa de obterem vantagens mútuas, entram em ação os elementos estruturais e processuais que tendem a formar a confiança e a identidade coletivas. Estas, confiança e identidade, ao interagirem, podem criar as expectativas de mudança pacífica que definem uma comunidade de segurança. (Adler e Barnett, 1998, p. 29 e pp. 37-48).

Completada esta cadeia de fatores, uma comunidade de segurança pode estar em um dos três seguintes estágios de desenvolvimento: nascente, ascendente ou madura. Esses estágios de desenvolvimento são metodologicamente admissíveis porque a abordagem de Adler e Barnett é construtivista e path-dependent, o que significa que, para eles, as comunidades de segurança são socialmente construídas e têm uma história, portanto, possuem 
um padrão evolutivo que segue o "arco do tempo" (nascimento, crescimento e maturidade) (Adler e Barnett, 1998, p. 49).

$\mathrm{Na}$ fase nascente de uma comunidade de segurança, os governos, embora ainda não necessariamente admitam a intenção ou possibilidade de construção de uma comunidade de segurança, começam a considerar como coordenar suas relações de modo a: aumentarem sua segurança mútua, reduzirem os custos de transação em suas trocas e encorajar interações futuras (Idem, p. 53).

$\mathrm{Na}$ fase ascendente, as redes de transações tornam-se cada vez mais densas, novas instituições e organizações refletem maior coordenação e cooperação militar e percepções de que os outros membros da comunidade representam menor ameaça. Nessa fase também surgem estruturas cognitivas que levam os membros a aprofundarem seu nível de confiança mútua e emergem identidades coletivas que iniciam as expectativas dependentes de mudança pacífica (Ibid, pp. 53-55).

O que também define as comunidades de segurança ascendentes é que elas apresentam uma convergência de idéias de bem-estar material e segurança que levam ao entendimento de que progresso e segurança podem ser garantidos apenas pelos membros que compõem a comunidade $^{10}$. A este respeito, observam-se, ao longo da história da América do Sul, práticas discursivas iniciadas no período Rio Branco e significativamente institucionalizadas apenas a partir das décadas de 1950 e 1960 e que objetivavam integrar os esforços dos governos do continente no sentido de se alcançarem tais bem-estar material e segurança. Este ponto será retomado na próxima seção.

Analisando-se o histórico de coordenações militares na América do Sul, a literatura que admite uma comunidade de segurança na América do Sul e se baseia nos conceitos de Adler e Barnett poderia considerar que esta comunidade está entre os estágios nascente e ascendente, pois, desde a década de 1980, existe uma coordenação técnica entre as Marinhas de Argentina, Brasil, Chile e Uruguai para patrulhar o Atlântico Sul (Flemes, 2005) e, a partir de então, é crescente o número de manobras e treinamentos conjuntos, intercâmbio de informações e coordenação operacional no nível administrativo.

Podem ser mencionadas, aqui, as conferências regularmente realizadas sob a Junta Interamericana de Defesa desde a década de 1960 e que incluem a participação dos comandantes-em-chefe das Forças Armadas do continente americano, o que seria um passo

\footnotetext{
${ }^{10}$ ADLER e CRAWFORD (eds.) Progress in Postwar International Relations. Apud Adler e Barnett, 1998, p. 53.
} 
inicial para a coordenação das Forças Armadas da América do Sul, que extrairiam desses encontros aprendizado técnico e organizacional no qual modelarem suas conferências e encontros particulares. Como fruto dessa aprendizagem, podem ser citados o X Simposio de Estudios Estratégicos de los Estados Mayores Conjuntos y de la Defensa, realizado em 1997 em Montevidéu e cujo tema foi $O$ Mercosul e a segurança sub-regional - conseqüências para o papel das Forças Armadas. Ainda pode ser referido o Encontro dos Ministros da Defesa, em Santiago do Chile, em novembro de 2002, quando foram definidas as novas ameaças à segurança regional: o terrorismo, o tráfico de drogas, o crime organizado, a venda de armas, a lavagem de dinheiro e a criminalidade virtual (Flemes, 2005, p. 4).

Esses dados, porém, são mais adequados a justificar um complexo de segurança na América do Sul, pois o conceito de comunidade de segurança somente se mantém aplicável quando não há, pelo menos na história recente, conflitos armados entre as forças militares dos países da pretensa comunidade, e a América do Sul, mesmo no século XX e até neste início do século XXI, apresentou conflitos envolvendo a participação de suas forças militares, como em janeiro de 1995, quando Peru e Equador confrontaram seus exércitos na disputa por um território de jurisdição questionada e, em 2008, no caso em que as forças militares da Colômbia ingressaram em território equatoriano para apreender lideranças das FARC. Apesar de este último exemplo não se tratar de uma ameaça Estado-a-Estado, a ausência de cooperação entre os governos a fim de resolverem um problema de segurança comum indica uma falência da hipótese de comunidade de segurança, qualquer que seja o estágio, na América do Sul.

Por outro lado, pode-se falar na construção de uma identidade comunitária sulamericana que constituiria um estágio prévio a uma eventual comunidade de segurança, ainda longe de ser alcançada. As práticas discursivas e cooperativas analisadas a seguir indicariam esse processo de construção identitária.

Por último, na fase madura de uma comunidade de segurança, ou seja, quando ela realmente passa a existir. Os outros estágios, apesar das denominações dadas pelos autores (Adler e Barnett, 1998, pp. 49-57), receberiam uma terminologia mais precisa se fossem chamados estágios de pré-comunidade de segurança), "it becomes increasingly difficult for the members of this 'region' to think only in instrumental ways and prepare for war among each other" (Adler e Barnett, 1998, p. 55). 
É dentro do tipo comunidade de segurança madura que aparecem os subtipos comunidades frouxas e vinculantes (ou mal casadas e bem casadas). Nas comunidades frouxas (mal casadas):

[...] states identify positively with one another and proclaim a similar "way of life"; there are multiple and diverse mechanisms and patterns of interaction that reinforce and reproduce the security community; there is an informal governance system based on shared meanings and a collective identity; and while there remains conflicting interests, disagreements and asymmetric bargaining, there is the expectation that states will practice self-restraint. (Idem)

Nas comunidades vinculantes (bem casadas), a ajuda mútua se arraiga entre os membros ao ponto de que suas identidades nacionais se expressem por meio da conciliação de esforços para a solução dos problemas de segurança comuns. O locus de exercício de poder é alterado em sua forma institucional e o direito de recorrer ao uso da força passa dos membros (unidades) da comunidade para a coletividade deles, sendo que a legitimidade desse uso da força está condicionada a que ele seja empregado apenas contra ameaças externas ou contra membros que infrinjam as normas da comunidade.

O conceito de comunidade de segurança, como desenvolvido pelos autores, não tem um mecanismo explícito para a definição de ameaças externas e, em tempos de transnacionalidade e compartilhamento do poder entre os Estados e outros atores, torna-se difícil operacionalizá-lo, conforme comprova o exemplo anterior, de FARC, Equador e Colômbia.

Os autores apresentam indicadores que confirmam a existência das comunidades frouxas e vinculantes. Todos os indicadores que se aplicam às primeiras são válidos para as segundas, mas não há reciprocidade nesta relação (Adler e Barnett, 1998, pp. 55-57). 


\begin{tabular}{|c|c|}
\hline Indicadores das comunidades frouxas & $\begin{array}{l}\text { Indicadores das comunidades } \\
\text { vinculantes }\end{array}$ \\
\hline $\begin{array}{l}\text { Multilateralismo que alcança facilmente o } \\
\text { consenso }\end{array}$ & $\begin{array}{l}\text { Todos os indicadores das } \\
\text { comunidades frouxas } \\
\end{array}$ \\
\hline $\begin{array}{l}\text { Fronteiras sem fortificação contra ameaças } \\
\text { militares dos outros membros }\end{array}$ & Segurança cooperativa e coletiva \\
\hline $\begin{array}{l}\text { Os cenários de worst-case não apresentam } \\
\text { os outros membros da comunidade }\end{array}$ & Alto nível de integração militar \\
\hline $\begin{array}{l}\text { Identificação comum da ameaça - a ameaça } \\
\text { é o outro, aquele fora da comunidade }\end{array}$ & $\begin{array}{l}\text { Coordenação política contra } \\
\text { ameaças internas }\end{array}$ \\
\hline \multirow{3}{*}{$\begin{array}{l}\text { Discurso e linguagem - o discurso reflete as } \\
\text { normas da comunidade e distingue-as de normas de } \\
\text { fora }\end{array}$} & $\begin{array}{l}\text { Liberdade de movimento } \\
\text { populacional }\end{array}$ \\
\hline & Internacionalização da autoridade \\
\hline & $\begin{array}{l}\text { Política de vários níveis - as } \\
\text { regras são compartilhadas nos níveis } \\
\text { nacionais, transnacionais e supranacionais. }\end{array}$ \\
\hline
\end{tabular}

Tabela 1. Indicadores da existência de comunidades de segurança frouxas e vinculantes.

A evidência de desintegração de uma comunidade de segurança é a presença de guerras e isso derruba a hipótese de que a América do Sul, em seus esforços cooperativos, constituiria uma comunidade de segurança ou pré-comunidade, pois, mesmo ao longo do século XX, foram observados conflitos militares na região.

\subsection{A América do Sul percebida como uma comunidade identitária - práticas discursivas e cooperativas}

"Integration is a matter of fact, not of time. If people on both sides do not fear war and do not prepare for it, it matters little how long it took them to reach this stage. But once integration has been reached, the length of time over which it persists may contribute to its consolidation."11

Para Andrew Hurrell, há uma comunidade de segurança frouxa, mas ainda imperfeita, no Mercosul, construída pela modificação nas relações entre Brasil e Argentina, que teriam se movido de uma relação de rivalidade para uma relação cooperativa. Esse trânsito, para o autor, não pode ser reduzido nem a considerações de poder nem a movimentos cooperativos de causalidade instrumental ou restrita a temas específicos (Hurrell, 1998, pp. 260-261). Para ele, trata-se de um processo que desafia tanto as teorias neo-realistas quanto neo-liberais por salientar três fatores: (i) é verificada, para o desenvolvimento dessa cooperação, importância crucial da construção histórica desses Estados e de seus padrões específicos de interação; (ii) os modos como mudanças paralelas de interesses e identidades facilitaram a cooperação não podem ser ignorados; (iii) as mudanças no padrão de cooperação foram produto tanto de

${ }^{11}$ DEUTSCH, Karl (1957): Political Community, p. 6. 
fatores domésticos quanto internacionais que se refletiram no processo em curso de institucionalização da cooperação, bem como foram reforçados por ele. As barreiras verificáveis ao processo de cooperação, para Hurrell, devem ser compreendidas como, por um lado, como produto das divergências de identidade persistentes e, por outro, como fruto de desincentivos e obstáculos materiais.

Este trabalho, como já esclarecido, não admite uma comunidade de segurança na América do Sul, em vez disso, lança a hipótese de que o continente vivencia um longo processo de construção da identidade comum, momento anterior ao de afirmação de uma comunidade. Portanto, a maneira de trabalhar com as abordagens divergentes, porém complementares, de Adler e Barnett, por um lado, e Buzan et al. (1998, 2003), por outro, seria aproveitar o arcabouço conceitual e metodológico daqueles primeiros autores para verificar se haveria, dentro de uma perspectiva construtivista, uma comunidade identitária, mas não de segurança, na América do Sul. Por outro lado, a metodologia e o conceito de Buzan et al., cujo argumento será desenvolvido a seguir, devem ser levados em consideração porque consideram a distribuição material do poder no continente, e este elemento não pode ser ignorado porque, a partir dele é que se pode avaliar se há condições objetivas de integração no continente. Em síntese, na visão da autora, a América do Sul seria uma comunidade identitária e complexo de segurança.

Para a verificação da primeira premissa (América do Sul como comunidade identitária, lembrando que a identidade é a terceira dimensão de uma comunidade, segundo Adler e Barnett), neste trabalho, utilizo-me da dissertação de Galvão (2003) para ilustrar como é possível perceber-se, na América do Sul, uma visão favorável a que a América do Sul constitui uma comunidade identitária, pois os requisitos de "conformação de um objetivo comum", "motivação por interesses comuns", "estabelecimento de regras de convívio e cooperação", "criação de instituições próprias de atuação interna e externa" e "inspiração em uma matriz cultural compartilhada" (Galvão, 2003, p. 3), que o autor apresenta para justificar a construção ideológica de uma América do Sul, são requisitos presentes no estágio précomunitário do que pode vir a tornar-se uma comunidade de segurança.

A obra de Galvão é relevante para a construção do argumento da autora porque analisa a história da criação de uma identidade sul-americana dentro de um processo histórico de práticas discursivas e cooperativas que remontam, pelo menos, ao período em que o Barão do Rio Branco esteve à frente da formulação da política externa do país, de 1902 a 1912. 
Galvão (2003, p. 21) retoma a literatura sobre a Política Externa do Brasil e caracteriza o período Rio Branco como um período marcado pelo juridicismo e pela preferência por soluções negociadas para os conflitos. Em 1909, o Barão redigiu o Tratado de Cordial Inteligência Política e Arbitramento entre os Estados Unidos do Brasil, República Argentina e a República do Chile, o que seria considerado um primeiro ensaio do arranjo $\mathrm{ABC}$ (Argentina, Brasil e Chile) e representou "possibilidade de equilíbrio das forças militares entre os países, principalmente no que tange à Marinha de Guerra" (Galvão, 2003, p. 26). Contudo, o Tratado não seria ratificado e a isso se atribuem os pontos de vista do ministro das relações exteriores argentino, Estanislao Zeballos, que acreditava numa tendência subimperialista do Brasil, articulado aos interesses norte-americanos na América do Sul. As desconfianças em relação ao outro dão a tônica das relações na região, sendo responsáveis pelos retrocessos e estagnações no encaminhamento da cooperação que poderia vir a configurar uma comunidade de segurança.

Outras personagens proeminentes no período Rio Branco, Joaquim Nabuco e Oliveira Lima, tinham visões opostas sobre o posicionamento internacional que o país deveria adotar. Joaquim Nabuco tinha uma visão otimista do pan-americanismo e era favorável a uma aliança com os Estados Unidos. Oliveira Lima tinha uma perspectiva crítica da relação com os norteamericanos e percebia-a como um perigoso pan-americanismo ditado pelo Norte. Rio Branco era considerado o mais pragmático e moderado em relação a filiações ideológicas e atribui-se a ele o ideal de consolidar primeiro as fronteiras do país e, depois, consolidar as relações entre os países sul-americanos sob o eixo ABC (Galvão, 2003, p. 25). O projeto embutido no Tratado de 1909 seria o de harmonização entre dois eixos, o simétrico (relações na América do Sul) e o assimétrico (relações com os Estados Unidos).

[...] o Pacto $\mathrm{ABC}$ seria em tese um esquema de não-agressão, entendimento e cooperação entre Argentina, Brasil e Chile, mas que na prática da política internacional se aproximaria mais de um condomínio oligárquico de poder a ser exercido pelas nações mais expressivas da América do Sul sob bases paradoxais: tanto com o respaldo norte-americano, quanto numa tentativa de escapar do panamericanismo como única estratégia de inserção internacional. (Galvão, 2003, p. $28)^{12}$

A prática discursiva do período Rio Branco foi coerente com a dinâmica cooperativa de encetar relações amistosas com os principais vizinhos do continente sul-americano. $\mathrm{O}$

\footnotetext{
${ }^{12}$ Ver também BUENO, Clodoaldo (2002). “O Barão do Rio Branco e o Projeto da América do Sul”. In Rio Branco, América do Sul e a Modernização do Brasil. Brasília: IPRI/FUNAG, p. 175.
} 
Brasil pretendia apresentar-se aos demais países da região como um país confiável, que desafiava a construção de uma identidade hispânica em oposição à identidade brasileira de herança lusitana e pretendia chamar a atenção para a possibilidade de uma identidade comum:

\begin{abstract}
Somos, na verdade, um povo que tem dado inequívocas provas de seu amor à paz e da sua longanimidade para com os mais fracos [...] esforçamo-nos sempre para viver na melhor harmonia com os demais países, particularmente com os que nos são limítrofes. Anelamos merecer o afeto, não a desconfiança ou temor dos nossos vizinhos (RIHGB, t 71, 1908, pp. 425-432. In ARAÚJO, J. H. Pereira de (2002): “O Barão do Rio Branco e o Instituto Histórico e Geográfico Brasileiro". In RIO BRANCO, América do Sul e a Modernização do Brasil. Brasília: IPRI/FUNAG, 2002, pp. 25-34 apud Galvão, 2003).
\end{abstract}

No período de 1946 a 1964, a Argentina, sob a influência modificadora do peronismo, passa a ter percepção favorável ao pacto $\mathrm{ABC}$ e o contexto é de convergência dos países sob a égide do desenvolvimentismo. As principais movimentações cooperativas nesse intervalo são a proposta de recriação do $\mathrm{ABC}$, por Perón, a Operação Pan-Americana de Juscelino Kubitschek, o Mercado Comum Latino-Americano e os concertos de Uruguaiana e Punta del Este.

A revisitação do Pacto $\mathrm{ABC}$ deu-se em três movimentos e sob maestria argentina. $\mathrm{O}$ primeiro foi o encontro de Dutra e Perón em Uruguaiana e Pasos de los Libres, com a inauguração da ponte sobre o Rio Uruguai, ligando os dois países, em 1947, e que desmistificou o peronismo, comprovando que Argentina e Brasil "tinham interesses a concertar que transcendiam governos e regimes políticos" (Galvão, 2003, p. 34). O segundo movimento foi a investida argentina para cooptar países à "terceira posição" com o fim de haver complementaridade político-econômica. A conjuntura era favorável por haver várias democracias populistas na região (Vargas no Brasil, Ibañez no Chile, Estensoro na Bolívia e Ibarra no Equador). O terceiro movimento iniciou-se com o lançamento da Ata de Santiago de 1953, em que foram lançadas as bases da união econômica chileno-argentina e à qual posteriormente adeririam, na América do Sul, Paraguai, Equador e Bolívia e, da América Central, a Nicarágua. A iniciativa fracassou por não contar com a participação de um concertista de peso. O Brasil retirara-se da orquestra durante o terceiro movimento porque, assim como a Argentina de Zeballos percebia veleidades hegemônicas no Brasil, o Brasil de 1954-1958 via o mesmo na Argentina, adicionando-se a isso a explicação de que, no período 1954-1958, a política externa brasileira caracterizou-se por "um hiato concernente à 
autonomia diplomática do Brasil frente aos EUA e à utilização dinâmica da política exterior como instrumento do desenvolvimento econômico nacional” (Galvão, 2003, p. 37).

A diferença de tempos entre Brasil e Argentina parece dar lugar a acordes mais harmoniosos apenas a partir de 1958, com o lançamento da Operação Pan-Americana por Juscelino Kubitschek e a mobilização que se gerou, na América do Sul, em torno do projeto de atrair a atenção norte-americana para a pobreza da América Latina, apontada pelos governos locais como fator de vulnerabilidade à influência comunista. Em 1960, seria assinado o Tratado de Montevidéu, constituindo a Associação Latino-Americana de Livre Comércio entre Argentina, Brasil, Chile, Peru, Paraguai, Uruguai e México. O empreendimento, apesar de significativo, trazia em si o paradoxo que o inviabilizaria: tentava conciliar políticas protecionistas geridas pelo paradigma nacional-desenvolvimentista e o modelo de expansão de mercados no nível regional. Além disso, outras deficiências eram "as dificuldades em compartilhar interesses, em detrimento de competições por áreas específicas e reduzidas da agenda negociadora, e um estatuto rígido, que engessou o arranjo e impediu que se adequasse às circunstâncias externas e demandas internas" (Galvão, 2003, pp. 43-44).

O Convênio de Amizade e Consulta entre Brasil e Argentina, o sinal para o despertar do freqüentemente referido na literatura como o Espírito de Uruguaiana (foi assinado nessa cidade gaúcha em abril de 1961), é que seria “o primeiro ensaio de uma possível integração mais ampla a ser seguida na América do Sul” (Galvão, 2003, p. 45). Além do Convênio, o encontro no Rio Grande do Sul conteve uma agenda de 11 pontos que previa, além de coordenação econômico-comercial entre os dois países, acordos de segurança coletiva aos quais os demais países da região poderiam aderir, se interessados.

Durante o período militar no Brasil (1964-1985), o evento cooperativo mais marcante para a região foi a Operação Condor, que promovia a integração pela via da coordenação militar e que fora um arranjo decorrente do próprio Espírito de Uruguaiana em dois aspectos. O primeiro deles institucional, pois, dentro do Convênio, fora criado um sistema permanente de consulta militar que seria a base da formação de uma rede de inteligência na América do Sul utilizada durante as ditaduras militares. E o segundo deles, ideológico, pois o Espírito de Uruguaiana plasmara uma identidade entre Argentina e Brasil que lhes permitia definirem em acordo qual era a ameaça comum. Entre as décadas de 1960 e 1980, essa ameaça era expressa pelo comunismo e pelas variadas formas de tentativa de subversão dos regimes autoritários. 
A partir da década de 1980, Argentina e Brasil reiniciam importantes movimentos de cooperação, caracterizando-se como os líderes dos quais depende a integração no continente sul-americano. Nesse contexto, os principais marcos jurídicos da integração foram: as Atas para a Integração Brasileiro-Argentina (1985-1986); o Acordo de Integração, Cooperação e Desenvolvimento (1988); o Tratado de Assunção (1991) e o Protocolo de Ouro Preto (1994), este último tendo outorgado ao Mercosul personalidade jurídica de Direito Internacional Público $^{13}$. O Mercosul, porém, apresenta falhas que estão na dificuldade de sua institucionalização e na nuclearização decisória entre Brasil e Argentina, o que estagna o processo de integração diante de divergências entre os dois países. Galvão (2003, p. 101) comenta que:

\footnotetext{
"O multilateralismo negociador no Mercosul permitiu o encaminhamento de soluções para problemas de cooperação entre os quatro países-membro, mas não ensejou a redistribuição da capacidade de influência e decisão no processo negociador, restrito a Brasil e Argentina, o que emperraria a evolução do Bloco na medida em que surgissem problemas e desagrados aos interesses individuais de ambos os lados." ${ }^{14}$
}

O ensaio pré-comunitário na América do Sul mostra-se, assim, dependente sobretudo da vontade política de Brasil e Argentina, que tentam afirmar uma identidade sul-americana e institucionalizá-la por meio da cooperação econômica, um fenômeno (regionalismo ${ }^{15}$ ) presente em várias partes do mundo globalizado. Contudo, as limitações dessa integração ainda se devem a dilemas históricos identitários (Galvão, 2003, p. 102) que se refere a que os países do Mercosul freqüentemente abram mão da racionalidade de bloco em favor de interesses particulares. Neste aspecto, a Argentina, tentando colocar um contrapeso à sua percepção de hegemonia brasileira, tentou negociações bilaterais com o NAFTA, sondou a possibilidade de negociar a ALCA $^{16}$ independentemente do Mercosul, pediu formalmente para ingressar na OTAN como membro especial e, ainda, chegou a disputar com o Brasil um assento permanente no Conselho de Segurança da ONU.

\footnotetext{
13 BERNAL-MEZA, Raúl (2000): Sistema Mundial y Mercosur: Globalización, Regionalismo y Políticas Exteriores Comparadas. Buenos Aires: Grupo Editor Latinoamericano. Pp. 309-324.

${ }^{14}$ A este respeito, ver também Vaz, 2002, pp. 275-287.

15 Para os conceitos de região, regionalização e regionalismo, ver CASTELLS, Manuel (1999): $A$ Sociedade em Rede. São Paulo: Paz e Terra.

${ }^{16}$ RAPOPORT, Mario (2002): "Entre El Mercosur y El ALCA: dilema actual o dilema histórico?" Tiempos de crisis, vientos de cambio: Argentina y el poder global. Buenos Aires: Grupo Editorial Norma.
} 


\title{
CAPÍTULO 2 - O CONCEITO DE COMPLEXO DE SEGURANÇA REGIONAL
}

\author{
$2.1 O$ conceito de complexo de segurança regional, inter-relação de níveis de \\ análise (constelação de segurança), variáveis e tipologia
}

\begin{abstract}
"We do not rule out the study of causal effects of, for example, cultural or economic patterns on security patterns. Quite the contrary, it is only by defining RSCs purely in security terms that this causal relationship is opened up for examination." (Buzan e Wæver, 2003, p. 44)
\end{abstract}

O conceito de complexo de segurança foi cunhado por Buzan (Buzan, 1983, p. 106) como "a group of states whose primary security concerns link together sufficiently closely that their national securities cannot reasonably be considered apart from one another" e desenvolvido como complexo de segurança regional em sua obra conjunta com Wæver e de Wilde (Buzan, Wæver e de Wilde, 1998, p. 201) nos termos: "a set of units whose major processes of securitisation, desecuritisation, or both are so interlinked that their security problems cannot reasonably be analysed or resolved apart from one another".

A sofisticação do conceito teve como objetivo, segundo os autores, ampliar seu escopo de aplicação, antes focado essencialmente em abordagens estatocêntricas e políticomilitares:"[...] the definition of RSCs [regional security complexes] was reformulated to shed the state-centric and military-political focus and to rephrase the same basic conception for the possibility of different actors and several sectors of security"(Buzan e Wæver, 2003, p. 44).

A ampliação do foco do conceito de segurança (da tradicional abordagem estatocêntrica para uma abordagem securitizadora de outros temas, como a política, o meio ambiente e a economia), no trabalho dos autores, como no aqui desenvolvido, ainda dá relevância às dinâmicas centradas no Estado, ou seja, o governo, com suas instituições e organizações formais, cujas decisões e poder de enforcement ainda são, pelo menos nas práticas formais e legitimadas (como a formulação e tomada de decisão em política externa), os mais poderosos na escala de atores das relações internacionais.

Tendo como base Buzan e Wæver (2003) e sua sumarização dos conflitos na América do Sul, é possível adotar-se um posicionamento oposto ao de que o continente configura uma 
comunidade de segurança. A partir da leitura destes autores, é possível chegar-se à conclusão de que a América do Sul configura, isto sim, um complexo de segurança regional.

A percepção de que o continente configuraria uma comunidade de segurança desconsidera o histórico dos conflitos na região e a dificuldade de conciliação de interesses entre os países, o que é demonstrado pelo estado latente de conflitos não solucionados e que pode se manifestar periodicamente nos discursos e práticas políticas dos países. Os autores mencionam que "[t]he region has been transnationally unified more at the level of ideas and ideals, where symbolic figures are often shared, whereas the level of interests and actions has remained more fragmented" (Buzan e Wæver, 2003, p. 318).

A construção do conceito de complexo de segurança regional (CSR) dentro da teoria dos complexos de segurança regionais (TCSR), elaborada por Buzan e Wæver, prevê que a estrutura do sistema internacional seja anárquica, neste caso, os CSR seriam uma subestrutura do sistema com forte poder explicativo para o entendimento de como as potências globais interferem nas dinâmicas das regiões do planeta, mas afirmando a relevância dos atores e dinâmicas regionais em impactarem as políticas globais e a estrutura internacional.

A proposição daTCSR dá-se num contexto em que a estrutura internacional bipolar se altera com o fim da Guerra Fria e os padrões de amizade e inimizade refletidos em conflitos e arranjos cooperativos regionais tornam-se mais explícitos. A proposição dos autores, a respeito da alteração de polaridade no pós-Guerra Fria, é de que o sistema internacional atual se estrutura numa polaridade $1+4+$ regiões, ou seja, Estados Unidos + (Japão, UE, China e Rússia) + regiões.

A TCSR concilia, por um lado, as perspectivas realistas e liberal-institucionalistas rechaçadas por Adler e Barnett e, por outro, as perspectivas construtivistas que esses autores adotam.

A consideração de Buzan e Wæver pelas teorias tradicionais de sistema internacional diz respeito à concordância com os seguintes pressupostos: a TCSR herda do paradigma realista a perspectiva de polaridade (unipolaridade, multipolaridade ou algum híbrido, como 1 $+4+$ regiões), ou seja, a distribuição material de poder determina a estrutura da política global e de segurança e segue a lógica do balanço de poder; do paradigma liberalinstitucionalista, a TCSR herda o pressuposto metodológico da racionalidade instrumental dos atores, expressa em suas práticas de comportamento recorrente (instituições) e no interesse de maximizar os resultados dessas interações. A herança construtivista aparece na teoria de 
Buzan e Wæver porque a formação e a operação dos CSR dão-se em função dos padrões de amizade e inimizade presentes entre as unidades do sistema, o que torna os sistemas regionais dependentes das ações e interpretações dos atores e não apenas da distribuição de poder (pp. 6-14 e p. 40$)^{17}$.

Apesar da concordância com pressupostos construtivistas e sociológicos, a premissa da TCSR é de que as dinâmicas culturais/civilizacionais são importantes, mas o que deve ser priorizado são as dinâmicas observáveis de securitização/dessecuritização entre os atores de uma região. Essas dinâmicas devem ser, dentro da teoria de Buzan e Wæver, ressaltadas a ponto de não importar, num primeiro momento, se os atores agrupados dentro de um CSR definem afinidades culturais ou identitárias: "We study the security discourses and security practices of actors, not primarily their regional(ist) discourses and practices. The latter is an interesting and important question (...) and is an element of our analysis, but not the basis of it. "(Buzan e Wæver, 2003, p. 48, grifos no original).

Para traçar essa linha argumentativa, os autores confrontam seu trabalho com o clássico de Huntington, Clash of Civilizations ${ }^{18}$, que prioriza os conflitos intercivilizacionais como mais decisivos do que os intracivilizacionais.

Para os formuladores da TCSR, essa premissa não leva em suficiente consideração o peso dos conflitos dentro das civilizações. Essa predisposição a dar mais relevância aos conflitos intercivilizacionais seria responsável, segundo os autores, por muitos dos desastres da política de Guerra Fria para o Sul da África, para o Sudeste e o Sul Asiáticos e para o Oriente Médio (Buzan e Wæver, 2003, p. 41). Além desse argumento, poder-se-ia acrescentar que negligenciar as dinâmicas intracivilizacionais no pós-Guerra Fria carrega consigo o risco de permitir que se agravem os conflitos regionais e locais, pois é notável que o fim da ordem bipolar trouxe o desinteresse das antigas potências globais (EUA e URSS) em sufocarem ou conterem os conflitos ao redor do mundo.

$\mathrm{O}$ argumento de Huntington defendia um papel fundamental dos atores globais na resolução dos conflitos intercivilizacionais, pois estes teriam a capacidade de alastrar-se pelo planeta. Buzan e Wæver consideram esse raciocínio apelativo para um público norteamericano, sobretudo após os atentados de 11 de setembro, mas afirmam que, do ponto de

17 Para uma conexão explícita entre as abordagens tradicionais e a abordagem construtivista, ver WENDT, Alexander (1999): Social Theory of International Politics. Cambridge: Cambridge University Press.

${ }^{18}$ HUNTINGTON, Samuel P. (1996): The Clash of Civilizations and the Remaking of World Order. New York: Simon and Schuster. 
vista da maioria dos demais Estados, "the relevant strategic setting is not primarily at the system level - the first priority is regional" (Buzan e Wæver, 2003, p. 41).

Segundo Nye Jr. (2003, p. 2), entre 1989, marco do fim da Guerra Fria, e o fim do século XX, o mundo vivenciou 111 conflitos em 74 localidades - sete foram conflitos interestatais e nove, intraestatais com intervenção internacional. Isso significa que, apesar de a maioria dos conflitos ter se dado dentro dos territórios dos Estados e, em grande parte dos casos, entre etnias ou grupos culturais em confronto (o que poderia ser utilizado favoravelmente ao argumento do clash of civilizations), o que se observa é que as dinâmicas regionais, e não globais, determinam com mais freqüência a deflagração de guerras, daí a atenção que a TCSR pretende dar para o nível de análise regional.

Retornando ao primeiro pressuposto da TCSR, a estrutura anárquica do sistema internacional, tem-se que o caráter dos CSR é determinado por dois tipos principais de relação (Buzan e Wæver, 2003, pp. 49-61): relações de poder e padrões de amizade e inimizade.

As relações de poder são definidas pela polaridade, que se manifesta tanto na estrutura do sistema internacional como dentro dos CSR, ou seja, dentro das subestruturas do sistema internacional. Nos CSR, assim, podem ser observados padrões de distribuição do poder em moldes unipolares, multipolares, unimultipolares etc.

O segundo de tipo de relação, os padrões de amizade e inimizade, são a dimensão socialmente construída da estrutura internacional, sendo a distribuição de poder a dimensão material (Buzan e Little, 2000, pp. 68-89).

Uma análise wendtiana (Wendt, 1999, p. 247) permite verificar os padrões de amizade e inimizade na estrutura anárquica do sistema internacional (que pode ser hobbesiana, lockeana ou kantiana) verificando que tipos de papéis (amigos, rivais ou inimigos) os atores adotam com predominância nesse sistema e como esses papéis estão internalizados (se por meio de coerção, interesse ou legitimação). A internalização de um dos papéis pode se dar por meio da coerção (originando-se, assim, numa fonte externa ao ator), por meio do interesse (o ator assume um papel conforme seus cálculos de perdas e ganhos) ou pela crença na legitimidade (entendimentos de certo e errado, bom e mau). Para a TCSR, a perspectiva wendtiana deve servir ao propósito de afirmar qual dos papéis será predominante num dado complexo, assim definindo sua característica básica (hobbesiano, lockeano ou kantiano).

Os padrões de amizade e inimizade são influenciados por fatores históricos, culturais, geográficos, mas a partir dessas variáveis abrangentes, não é possível delinear claramente os 
rumos individuais dos vários complexos de segurança ao redor do mundo. Em grande medida, o melhor exemplo para cada um deles é ele mesmo, isso decorre do curso path-dependent da história (Buzan e Wæver, 2003, p. 50).

O principal propósito da TCSR é atuar como uma moldura para os estudos empíricos de segurança regional. Para tanto, ela determina o que deve ser levado em consideração dentro de quatro níveis de análise a serem inter-relacionados e que são denominados a constelação de segurança (Buzan e Wæver, 2003, p. 51). Esses quatro níveis são discriminados na Tabela 2.

\begin{tabular}{|c|c|}
\hline $\begin{array}{l}\text { Níveis de } \\
\text { análise }\end{array}$ & Pretensão explicativa \\
\hline $\begin{array}{l}\text { Nível } \\
\text { doméstico }\end{array}$ & $\begin{array}{l}\text { Pretende levantar as vulnerabilidades domésticas dos estados } \\
\text { componentes do CSR, pois a especificando essas vulnerabilidades é possível } \\
\text { definir o que eles consideram ameaças ou objetos de securitização. }\end{array}$ \\
\hline $\begin{array}{l}\text { Nível } \\
\text { interestatal/regional }\end{array}$ & $\begin{array}{l}\text { A densidade nas teias de relacionamento entre um grupo de estados é o } \\
\text { que define a região a ser trabalhada na TCSR. Geralmente, a região é definida em } \\
\text { bases de contigüidade/ proximidade geográfica. }\end{array}$ \\
\hline $\begin{array}{l}\text { Nível } \\
\text { interregional }\end{array}$ & $\begin{array}{l}\text { O nível interregional é, geralmente, menos ativo do que o nível regional. } \\
\text { Exceções ocorrem quando, em situações de grande assimetria, um complexo sem } \\
\text { uma potência global, mas que é vizinho de um CSR que possua uma, passa a } \\
\text { densificar sua teia de relacionamentos com essa outra região. }\end{array}$ \\
\hline $\begin{array}{ll}\text { global } & \text { Nível }\end{array}$ & $\begin{array}{l}\text { Trata-se de esclarecer a interação entre os níveis regional e global, ou seja, } \\
\text { como as potências globais interferem na região. }\end{array}$ \\
\hline
\end{tabular}

Na TCSR, os quatro níveis de análise estão ativos, mas o grau em que isso ocorre é determinado por meio de observação empírica caso a caso. É, porém, um pressuposto da teoria que, em geral, o nível regional seja o mais ativo, ou seja, aquele com maior capacidade explicativa para a análise de um CSR. Região, para Buzan e Wæver, é definida em termos geográficos.

A fim de operacionalizar seu conceito de CSR, os autores partem do pressuposto de que as ameaças mais alarmantes para os Estados são as ameaças que viajam curta distância, o que geralmente implica trânsito sobre áreas geográficas contíguas ou próximas. Além disso, para os autores, a região, no conceito de CSR, precisa ser definida em termos geográficos porque, para eles, as relações entre os atores são mais intensas quanto mais próximos eles estiverem uns dos outros. As teorias construtivistas, porém, ressalvam que nem todas as regiões precisam ser baseadas geograficamente. Elas podem ser definidas em termos de identidade cultural, religiosa, lingüística, étnica etc. A aceleração dos fluxos de comunicação, 
mercadoria, finanças etc. e a transnacionalidade são fatores colaboradores para a configuração de regiões sobre novas bases que não as geográficas.

A componente geográfica, porém, é mantida como central na definição dos CSR porque determina as estruturas internas e as fronteiras externas que podem ser utilizadas para monitorar as continuidades e mudanças do complexo, além de permitir a distinção entre eventos mais e menos relevantes. Graças à definição de um CSR em termos geográficos é que se pode dizer que os CSR são duráveis na estrutura do sistema internacional (a durabilidade também está relacionada à dificuldade temporal em se modificarem os padrões de polaridade e balanço de poder na região), embora não permanentes, e que se pode apreender o propósito descritivo da TCSR, que é estabelecer um marco com o qual identificar e avaliar as rupturas no nível regional, por meio de quatro variáveis que compõem a estrutura essencial de um CSR (Buzan e Wæver, 2003, p. 53):

\begin{tabular}{c|c}
\hline \hline \multicolumn{1}{c||}{ Variáveis } & Definição \\
\hline \hline Fronteira & $\begin{array}{c}\text { As fronteiras separam os CSR e isolam seus membros, pois a } \\
\text { participação de um país em um CSR é exclusiva, diferentemente do que ocorre } \\
\text { com sua participação em subcomplexos. }\end{array}$ \\
\hline \hline $\begin{array}{c}\text { Estrutura } \\
\text { anárquica }\end{array}$ & Um CSR deve ser composto por, pelo menos, duas unidades autônomas. \\
\hline \hline Polaridade & É a distribuição de poder entre as unidades de um CSR. \\
\hline \hline Construção & $\begin{array}{c}\text { Dá-se de acordo com os padrões de amizade e inimizade entre os } \\
\text { membros/unidades de um CSR. }\end{array}$ \\
\hline \hline
\end{tabular}

Tabela 3. As variáveis que compõem um CSR.

Existem três possíveis evoluções para um CSR, todas relacionadas à preservação ou alteração nas variáveis estruturais do complexo. Em primeiro lugar, um CSR pode manter seu status quo, ou seja, não alterar significativamente sua estrutura, entendida aqui como suas variáveis componentes, explicadas na tabela acima. Em segundo lugar, um CSR pode sofrer transformações internas, que podem ser modificações na estrutura anárquica (via, por exemplo, integração regional), na polaridade (por meio da anexação de um CSR a outro ou a uma potência externa, desintegração, modificação dos índices de crescimento etc.) ou nos padrões de amizade e inimizade (o que pode ocorrer com a chegada de novos ventos ideológicos, mudança de lideranças, guerras etc.). Por último, um terceiro caminho evolutivo para os CSR são as transformações externas, ou seja, as alterações conjunturais ou estruturais nos níveis interregional ou global modificando o número de unidades num CSR e, provavelmente, alterando sua estrutura. Uma das formas como esse terceiro caminho pode se 
manifestar é com a fusão de um ou mais CSR. Como as transformações de ordem externa podem ter impacto na estrutura interna de um CSR, não é incompatível afirmar-se que as modificações de polaridade alteram a estrutura interna de um CSR sendo que essa nova polaridade decorre de um fator externo, qual seja, a anexação de um CSR a outro CSR ou uma potência externa.

As tipologias de um CSR são dadas de acordo com a polaridade observada no complexo. Existem quatro possibilidades típicas para um CSR: complexo padrão, complexo centrado, complexo de segurança de grandes potências e supercomplexo (Buzan e Wæver, 2003, pp. 55-63).

Um complexo padrão é vestfaliano, com duas ou mais potências definindo a estrutura anárquica e uma agenda de segurança predominante político-militar. A polaridade num complexo padrão é definida inteiramente por potências regionais (diferentemente do complexo centrado, em que a polaridade é definida por uma grande potência, superpotência ou por instituições atuantes no nível global), podendo ser unipolar ou multipolar.

Se o complexo padrão for unipolar, há apenas uma potência regional e que não atinge o nível de potência global. Neste tipo de complexo, existe uma clara distinção entre os níveis regional e global. Para Buzan e Wæver (2003, p. 57), os padrões de amizade e inimizade podem ser de formação de conflito, de regimes de segurança ou de comunidades de segurança.

Num complexo de segurança padrão, o principal componente da política de segurança é a relação entre as potências regionais da região, pois são elas que determinam a penetração do CSR por potências globais, bem como formulam as diretrizes de segurança a serem seguidas pelas potências menores dentro do complexo. Em alguma medida, este pode ser considerado o caso da América do Sul, um CSR padrão com duas potências regionais (Brasil e Argentina) que determinam, a partir dos avanços e retrocessos cooperativos em suas relações bilaterais, a dinâmica de segurança de toda a região.

Antes de passar à explicação dos demais tipos de CSR, é necessário esclarecer o porquê dos seguintes termos apresentados acima: formação de conflito, regimes de segurança, comunidades de segurança e penetração. Os três primeiros termos são as gradações que podem ocorrer nos padrões de amizade e inimizade dos atores e têm paralelo com as estruturas sociais hobbesianas, lockeanas e kantianas de Wendt ou com as três tradições da Escola Inglesa: hobbesiana, grotiana e kantiana (Cutler, 1991; Wæver, 1989 apud Buzan e 
Wæver, 2003, p. 47; Wendt, 1999). Notar que Buzan e Wæver consideram as comunidades de segurança um dos padrões de amizade que os CSR podem apresentar. Aqui, a opção é por separar os conceitos de comunidade de segurança e complexo de segurança, pois o entendimento da autora é de que um complexo de segurança, ao assumir o padrão de comunidade de segurança, torna-se uma comunidade de segurança.

Já penetração é um conceito que significa a atuação de uma potência global nos assuntos de um CSR ao qual ela não pertence, contudo sem retirar a autonomia dessa região em formular suas próprias políticas de segurança. Um conceito correlato ao de penetração é o de overlay, que significa uma potência incluir em sua área de atuação uma região que não corresponde à sua, a tal ponto de sufocar as dinâmicas regionais de segurança e tornar os alinhamentos das potências overlaid dependentes dos padrões de rivalidade, amizade e inimizade da grande ou superpotência. A diferença entre penetração e overlay é, portanto, que, neste último, o grau de ingerência é mais elevado. Uma evidência de overlay é o estacionamento de tropas estrangeiras num território durante um longo período. Assim, a Europa no pós-Segunda Guerra Mundial foi overlaid pelos Estados Unidos, assim como a África, a Ásia e as Américas o foram pela Europa durante o período colonial. Durante a Guerra Fria, o Nordeste e o Sudeste Asiático não chegaram a ser overlaid pelos Estados Unidos porque, nessas regiões, as dinâmicas de segurança interna se mantiveram intensas e com margem de autonomia maior do que nos casos europeu e colonial. (Buzan e Wæver, 2003, pp. 61-63). A respeito da influência norte-americana na América do Sul, desde as independências, pode-se falar em penetração, não em overlay e a influência das maiores potências (Argentina e Brasil) nas dinâmicas dos outros países do continente sul-americano não podem ser consideradas nem overlay nem penetração porque esses conceitos somente são aplicáveis para influências de uma potência externa ao CSR.

O segundo tipo de CSR, o complexo centrado, difere do complexo padrão basicamente porque as potências (ou instituições, para este caso) atuantes não são regionais, são grandes ou superpotências. Existem três tipos de complexo centrado: complexos centrados em grande potência, complexos centrados em superpotência e complexos centrados em instituições. Nestes complexos, o principal ator concentra-se nas dinâmicas globais, assim, as dinâmicas de segurança regionais são distorcidas e, em alguns aspectos, suprimidas. Todavia, "since all other actors in the region have their concerns linked to each other, a general map of global security would still show a clear regional formation of densely knit connections compared to 
a lack of connections in and out of the region for most units. This therefore can be still treated as an RSC" (Buzan e Wæver, 2003, p. 56). Exemplo de complexo centrado em grande potência é a Rússia na Commonwealth of Independent States. Para o caso de um complexo centrado em superpotência, tem-se a América do Norte centrada nos Estados Unidos e, para o modelo de um CS em instituições, o exemplo clássico é a União Européia. Uma ressalva para este último caso é que a UE também poderia ser percebida como uma grande potência ${ }^{19}$ ou, segundo os autores, como uma "comunidade de segurança em forma de CSR" (Buzan e Wæver, 2003, p. 58).

Perceber a UE como uma comunidade de segurança em forma de CSR é um ponto crítico da TCSR, segundo seus autores, porque, de um lado, os CSR exigem que haja dinâmicas de securitização e, de outro, as comunidades de segurança exigem dinâmicas de dessecuritização, ou seja, que "actors stop treating each other as security problems and start behaving as friends. They still compete and feel challenged now and then, but this is dealt with as normal political, economic, environmental and societal problems - not as matters of security, i.e., threats to survival that mobilise extreme countermeasures" (Buzan e Wæver, 2003, pp. 55-6).

A preocupação com a sustentabilidade de sua teoria seria aliviada se Buzan e Wæver admitissem que um complexo de segurança, ao assumir os padrões de uma comunidade de segurança, deixa de ser CSR e torna-se comunidade, já que a simultaneidade de dinâmicas securitizadoras e dessecuritizadoras torna metodologicamente difícil determinar a natureza (complexo ou comunidade) de um grupo de atores.

Caso os autores mantenham a opção por deixar a UE na zona cinzenta entre um CSR e uma comunidade, um fator favorável ao argumento de que a UE constitui um CSR é a verificação de fortes dinâmicas securitizadoras em relação aos membros mais recentes da União.

Outro elemento securitizado, desta vez segundo os autores, na Europa é a própria Europa, ou seja, o medo de que o passado europeu de políticas rivais e balanços de poder retorne, daí as medidas de integração: “As often stated explicitly in Europe, because of the risk of a return to power balancing, rivalry, and thereby eventually war, we Europeans have

\footnotetext{
19 "In the case of the EU, centredness comes not from the domination of a single pole of power, but from the building by a group of states of collective institutions that are beginning to take on actor quality in their own right" (Buzan e Wæver, 2003, p. 58).
} 
to do this (integrate) and abstain from that (beggar-thy-neighbour or rival intervention policies)” (Buzan e Wæver 2003, p. 57).

O ponto comum entre os três tipos de complexo centrado (centrado em grande potência, centrado em superpotência ou centrado em instituições) é que as dinâmicas de segurança da região são dominadas por um centro situado dentro da região. Isso levanta questões acerca de quão dominante é o centro (grau de assimetria de poder) e qual é a forma de hegemonia estabelecida. O estabelecimento da forma hegemônica depende de como se dá a internalização da estrutura social. Se a coerção for o mecanismo de imposição da hegemonia, ela será estabelecida de modo mais superficial do que se a hegemonia se estabelecer sobre as bases da legitimidade. Legitimidade, aqui, é definida como "the degree of acceptance (also among the peripheral units) of centredness as natural and correct, not imposed against some timeless standard of maximum independence"(Kratochwil, 1989; Watson, 1992; Wendt, 1999).

O terceiro e o quarto tipos de complexo de segurança, os complexos de grandes potências e supercomplexos, são os casos em que há mais de uma potência global atuantes na mesma região. Quanto maior o número de potências globais numa região, mais difícil o processo de centralização em um CRS do tipo anterior. Exemplos de CRS de grandes potências são a Europa dos balanços de poder (até 1914) e, atualmente, a Ásia sob a bipolaridade sino-japonesa. Duas diferenças do CRS de grandes potências em relação aos tipos anteriores são que: (i) as dinâmicas neste complexo afetam os cálculos de segurança em nível global; (ii) a presença de potências globais tem efeito de spillover nas regiões adjacentes, o que implica maior intensidade das interações interregionais.

Os supercomplexos de segurança, último tipo de CRS, decorrem do spillover de atuação das grandes potências de um complexo de grandes potências em regiões adjacentes a este complexo. Buzan e Wæver (2003, p. 60) afirmam que um supercomplexo é baseado em mais de uma grande potência. Grandes potências formam um supercomplexo quando suas interações interregionais afetam regiões fora daquela onde elas estão situadas. A constelação de segurança (níveis de análise interrelacionados pela TCSR) torna-se mais elaborada que o usual, neste caso. Aos tradicionais níveis doméstico, regional e global, deve ser adicionado o nível superregional, em substituição ao nível interregional. 
In a supercomplex, the interregional level is strong and sustained, as it has been between Northeast Asia and South Asia, but not so strong as to override the regional dynamics in the penetrated RSC (in this case, South Asia). If the interregional dynamics do override the regional ones, as happened during the 1990 s between Northeast and Southeast Asia, the spillover subordinates the previous patterns of regional security dynamics, and the component RSCs within the supercomplex undergo external transformation, merging to form a new and larger RSC (in this case, East Asia). (Buzan and Wæver, 2003, pp. 60-1).

O objetivo da TCSR é gerar uma moldura analítica para comparar as regiões do mundo, o que não pode ser feito sem um corpo conceitual e uma metodologia que indique os critérios a serem utilizados na delimitação dessas regiões. O que deve ser comparado nessas regiões são as relações de poder e os padrões de amizade e inimizade que determinam a ausência ou a contenção de conflitos. Com o objetivo de permitir a conexão entre os fenômenos que levam ao não-conflito nas diferentes regiões do mundo (e o principal critério para a definição de região, na obra de Buzan e Wæver, é o geográfico), o conceito de complexo regional de segurança e a TCSR pretendem:

1) separar os níveis global e regional a fim de estudar a relação entre ambos (a TCSR tem como aparato funcional a elaboração de vários níveis de análise para operacionalizar o conceito, como explicado acima);

2) isolar os CSR, criando o pressuposto da participação excludente de um país em um outro complexo, exceto nos casos específicos de subcomplexos e supercomplexos, decorrente de dinâmicas intra-regionais e interregionais, respectivamente, mais intensas do que a dinâmica propriamente regional;

3) a partir da definição da estrutura de um CSR, a teoria propõe estudar que elementos levam à mudança de um complexo ou nele;

4) determinar de um modo geral, com o conceito de CSR, que formatos uma região pode assumir e, assim, possibilitar análises prospectivas sobre que tipos de mudanças podem ocorrer num CSR, dados suas condições específicas e o padrão historicamente observado. 


\title{
2.2 A América do Sul percebida como um complexo de segurança regional
}

\begin{abstract}
"The possibility of war certainly has not been absent from the continent: military force has been threatened or used more than two hundred times in the twentieh century [...]. South America has not been a security community or anything close to it." (Buzan e Wæver, 2003, p. 304) ${ }^{20}$
\end{abstract}

A América do Sul compõe um complexo de segurança regional padrão, ou seja, possui pelo menos duas potências regionais, Brasil e Argentina, cuja interação bilateral condiciona as dinâmicas do continente sul-americano e estabelece as diretrizes para sua integração. É um complexo "marked by domestic social tensions and political instability, regional rivalries and transnational spillovers, and great power, mainly American, interventionism" (Buzan e Wæver, 2003, p. 309). O continente, ainda, está dividido em dois subcomplexos de segurança: um subcomplexo andino (composto por Equador, Colômbia, Peru e Bolívia ${ }^{21}$ ) e um subcomplexo de segurança do Cone Sul (membros do Mercosul, Bolívia e Chile). Os subcomplexos têm a mesma definição dos complexos de segurança, mas as redes mais densas de interação entre determinados países demandam uma unidade de análise mais específica, embora as dinâmicas gerais entre a totalidade desses países ainda permita seu enquadramento na moldura maior do complexo de segurança regional. Uma diferença entre os subcomplexos e os CSR é que as unidades podem pertencer a um ou mais subcomplexos, enquanto a participação em um CSR é excludente.

Os principais temas de segurança na região são a guerra às drogas, no subcomplexo andino, e o futuro do Mercosul, no Cone Sul (Buzan e Wæver, 2003, p. 304). Numa visão mais atual dos autores que embasam esta parte do trabalho (Buzan e Wæver), podem também ser mencionados como temas relevantes a segurança societal (povos indígenas, a violência urbana e rural) e as diversas formas de contrabando transfronteiriço, bem como práticas de degradação ambiental, como o desmatamento ilegal na Amazônia.

A guerra às drogas, ou seja, uma ameaça transnacional envolvendo, sobretudo, Colômbia, Bolívia e Peru, poderia ser definida como um problema de segurança política, se forem tomadas as principais categorias de segurança ou temas securitizáveis que Buzan e Wæver apresentam em seu trabalho de 1998: segurança societal, ambiental, política e

\footnotetext{
${ }^{20}$ Para os dados acerca do número de conflitos ou ameaça de conflitos militares no século XX, Buzan e Wæver fazem referência a MARES, David R. (1997): "Regional Conflict Management in Latin America: Power Complemented by Diplomacy" In LAKE, David A.; MORGAN, Patrick M. Regional Orders: Building Security in a New World. University Park: Penn State University Press. Pp. 195-218.

${ }^{21}$ Buzan e Wæver adicionam Venezuela e Guiana (2003, p. 317).
} 
econômica (Buzan e Wæver, 1998). A segurança política diz respeito à estabilidade organizacional dos Estados, sistemas de governo e ideologias que dão aos governos e Estados sua legitimidade (Buzan e Wæver, 1998, pp. 141-162).

Os conflitos com milícias paramilitares de direita e com as FARC, de esquerda, têm enfraquecido o Estado colombiano e sua capacidade de garantir os direitos de segurança dos cidadãos, que ficam expostos à fragilidade das instituições estatais e aos ataques dos grupos subversivos.

Também no subcomplexo andino é relevante a securitização do meio ambiente, pois há a necessidade de se combater o degelo andino, cujas implicações alterarão o clima da região e os modos de vida das populações, por exemplo, tornando-as mais vulneráveis aos efeitos do El Niño e alterando os regimes de pesca com o aumento do volume dos rios, além de afetar a biodiversidade. Ainda há, também em meio ambiente, a necessidade de proteção da Amazônia e de manejá-la de forma sustentável, o que abre a possibilidade de se considerar também um subcomplexo amazônico, que dê relevância, novamente, à biodiversidade e ao combate ao desmatamento e aos ilícitos transnacionais, como tráfico de drogas e biopirataria.

Para o caso da América do Sul, é interessante notar, a este respeito, que a Venezuela ou o Chile podem ser incluídos tanto no subcomplexo andino quanto no subcomplexo do Cone Sul, de acordo com o objetivo, o recorte teórico e a opção metodológica do analista.

Notar que os países aqui definidos como pertencentes ao subcomplexo de segurança andino são os mesmos que, atualmente, compõem a Comunidade Andina de Nações. A Venezuela, que se retirou da Comunidade em 2006, participa das dinâmicas do subcomplexo e sua participação, recentemente, refere-se, sobretudo, ao apoio do governo Chávez às FARC, gerando indisposições com a Colômbia. A dotação em recursos naturais importantes como o petróleo também é um fator de peso para a relevância desse país. O Chile, que se retirou da Comunidade (então Grupo Andino) será admitido como membro do subcomplexo do Cone Sul, dada a intenção histórica de Brasil e Argentina em integrá-lo a um pacto ABC, estratégia decorrente da percepção de relevância desse país em vários aspectos, como o econômico, cultural, social e que o aproximaria mais de Brasil e Argentina do que dos países do entorno andino.

As dinâmicas de segurança divergem nos dois subcomplexos porque as percepções de ameaça e as soluções cooperativas trabalhadas são distintas para os dois, e porque uma rede interativa mais densa é observada dentro de cada um desses subcomplexos, o que decorre das 
diferentes percepções de ameaça a serem securitizadas e das características distintas em vários outros aspectos: econômico, político, social etc.

A segurança interestatal tem sido secundária nos assuntos domésticos, mesmo assim, as guerras não estão fora da história do continente, mesmo que os conflitos do século XX possam ser considerados menos destrutivos do que os do século anterior (Buzan e Wæver, 2003, p. 304). As guerras do continente foram principalmente motivadas por disputas de fronteira, uma herança do processo de consolidação dos Estados independentes após o domínio ibérico. Apesar da necessidade de delimitar territórios de propriedade indefinida, a maior influência do período colonial para as relações no continente, segundo Buzan e Wæver terá sido a diferença entre as identidades lusitana e hispânica.

A formação de um complexo de segurança na América do Sul iniciou-se como um processo de formação de conflito, um processo verificável também em outras regiões póscolonizadas, como a África e a Ásia, que, na ausência de suas metrópoles, definiriam territórios e padrões de amizade e inimizade sob a influência dos interesses locais e regionais de grupos econômicos, étnicos ou políticos específicos.

No século XIX, as guerras de maior relevância para a formação dos Estados sulamericanos foram: de 1825 a 1828, a Guerra Cisplatina, entre Brasil e Argentina e que resultou na formação do Uruguai; a Guerra do Paraguai, de 1865-1870 e a Guerra do Pacífico, de 1879 a 1883, em que Chile conquistou territórios do deserto do Atacama, ricos em recursos minerais, reivindicados por Bolívia e Peru - ao final deste conflito, a Bolívia perdeu o acesso ao mar. No século XX, entre 1931 e 1935, a descoberta de petróleo no sudeste boliviano levou à Guerra do Chaco, entre Bolívia e Paraguai, com vitória deste último; entre 1932-3, Peru e Colômbia disputaram a região de Letícia; entre 1939 e 1941, em 1981 e em 1995, Peru e Equador vivenciaram uma disputa do Equador por acesso à navegação na bacia amazônica e o Conflito de Zarumilla, uma disputa territorial por uma área com reservas de ouro, urânio e petróleo - apenas em 1998 os países assinaram um tratado de paz com a definição de suas fronteiras (Buzan e Wæver, 2003, p. 304; Hurrell, 1998, p. 261).

Além dos conflitos efetivos, ainda há conflitos latentes, que se trata de disputas atuais sobre territórios: entre Colômbia e Venezuela, disputa pela fronteira marítima do Golfo da Venezuela; entre Venezuela e Guiana Inglesa, disputa pelo território do rio Essequibo, com reivindicação venezuelana de cinco oitavos do território guianense. Outros conflitos estão aparentemente resolvidos, como a disputa entre Argentina e Chile por territórios no Ártico, 
suspensa pelos Tratados Antárticos de 1961, mas com possibilidade de retorno dadas as reivindicações adicionais de terceiras partes (Brasil e Grã-Bretanha) e as pendências chilenoargentinas de disputas anteriores sobre territórios ao sul do continente sul-americano, como as ilhas da Terra do Fogo.

Os conflitos internos aos países sul-americanos, apesar dessas rivalidades interestatais, ainda são mais sangrentos e continuados, o que define a instabilidade interna aos países como um problema maior e prioritário, em detrimento da preocupação de um Estado com as ameaças representadas por outro. Entre as principais guerras civis sul-americanas no século XX estão: a Violencia colombiana, de 1949 a 1962; a repressão dos subversivos ao regime chileno, de 1973 a 1977; a Guerra Suja da Argentina, de 1976 a 1980; o combate ao Sendero Luminoso no Peru, de 1986 até o início do século XXI e, perdurando há mais de 40 anos, a crise interna colombiana, em conflito governamental com as milícias paramilitares e as FARC.

Durante a Guerra Fria, o principal tema securitizado no CSR sul-americano foi a ameaça comunista. Vários regimes militares instalaram-se, o que demonstra um padrão observável de spillover de regimes políticos na região: as ondas democráticas e populistas, bem como conservadoras, não se restringem a um único país, tendendo a se espalharem pelos demais. As polarizações domésticas pré-existentes alinharam-se nos moldes da Guerra Fria (capitalistas $x$ socialistas; pró-EUA $x$ pró-URSS).

As elites latino-americanas formulavam doutrinas de segurança nacional baseadas no perigo de expansão do comunismo e securitizavam dentro dessa ameaça as demais formas de subversão aos regimes políticos. Vários movimentos subversivos/revolucionários tomaram a forma de guerrilhas. O processo de securitização, muitas vezes, fortalecia o que era visto como ameaça, pois as formas subversivas respondiam agressivamente à medida em que percebiam que seus agentes securitizadores alinhavam-se a uma ameaça percebida como ainda maior, os Estados Unidos: "This securitisation also stimulated that which it depicted as a threat, because close regime alignment with the USA fed into the threat images of the left according to which the main security problem was the USA.” (Buzan e Waever, 2003, p. 312).

Apesar da possibilidade de não-alinhamento aos padrões da Guerra Fria sob movimentos de defesa de uma nova ordem internacional, de campanhas pelo Terceiro Mundo etc., a Guerra Fria politizou e internacionalizou a violência na América do Sul. 
A segurança numa região está condicionada, em grande medida, pela forma como se estruturam os Estados (Hurrell, 1998, p. 239) e

the state in South America seems to occupy a middle way in the weak/strong state continuum: it has been strong enough not to fall apart as in other postcolonial situations (like those in Africa). At the same time, it has been weak enough to find it hard to mobilize its society from war and conquest" (Kacowicz, 1998, p. 107 apud em Buzan e Waever, 2003, p. 312).

Apesar da convergência dos países sul-americanos na definição de uma ameaça comum durante a Guerra Fria, os padrões de alinhamento não foram consistentes para a configuração de um complexo de segurança mais integrado:

Even the most consistent pattern of alignments - Brazil-Chile and Argentina-Perunever consolidated into a kind of European-style bipolarisation and fixation of alliances, because the conflicts were too many and interests therefore crosscutting. In this respect, the RSC is moderately integrated. It is not integrated as much as if it had one overriding conflict or integrative project, but the different conflicts and securitizations have independent roots that tie together as they develop (Buzan $\mathrm{e}$ Wæver, 2003, p. 317).

Os conflitos na América do Sul não se alinham a um padrão de alianças, mas há a tendência de que um conflito desencadeie vários outros:

Chile's conflict with Argentina has been seen as part of the balance-of-power system in the Southern Cone. Alliances have mostly been rather informal ententes. Chile has historically acted to prevent a possible Peru-Bolivia-Argentina axis; Argentina worried about a Brazil-Chile alliance. Also, interconnected conflicts show simply in the worry that a third state would be able to exploit the weakening of one part of a conflict [...]" (Idem, p. 316)

O período da Guerra Fria foi, ainda, o de maior influência dos Estados Unidos sobre a América do Sul e a América Latina em geral, pois a "defesa da democracia" passou a ocupar posto prioritário na agenda dos Estados Unidos, além de adquirir, como assunto prioritário, o status de assunto de segurança (Atkins, 1999, pp. 47-49).

No pós-Guerra Fria, as três principais modificações domésticas nos Estados foram: a democratização, a redução da influência dos militares no governo e reformas neoliberais com a internacionalização das economias (Buzan e Waever, 2003, p. 320).

A democratização aumentou a previsibilidade do comportamento dos Estados e as chances de cooperação regional. Isso é válido especialmente para o Cone Sul. O novo papel 
dos militares no continente é o da segurança cooperativa, envolvendo ações conjuntas das Forças Armadas dos países sul-americanos na defesa de ameaças transnacionais comuns, como as migrações ilegais, a biopirataria, o desmatamento e o narcotráfico.

Outros dois elementos securitizados (que enfrentam ameaças existenciais) com mais evidência depois da Guerra Fria são a preservação dos direitos indígenas e o desenvolvimento social. No primeiro caso, observam-se movimentos políticos nativistas importantes, sobretudo no Peru, no Equador, na Bolívia e, em uma proporção menor, também no Brasil. Esses movimentos exemplificam a segurança societal, segundo a qual há ameaças existenciais quando a identidade de um povo corre o risco de ser suprimida pela forma como outra sociedade - a não-índia, neste caso - expande seu modo de vida e afeta os padrões socioculturais daquele povo (Buzan e Wæver, 1998, p. 119).

O segundo tema na nova agenda de segurança, o desenvolvimento social, é um tema, na verdade, mais tradicional, cuja presença na cooperação regional remonta pelo menos à Operação Pan-Americana de Juscelino Kubitschek, uma tentativa de barganhar auxílio dos Estados Unidos contra a pobreza que, argumentou-se à época, tornaria os países vulneráveis às influências comunistas.

As mudanças mais expressivas no CRS sul-americano no pós-Guerra Fria ocorreram no Cone Sul e alteraram o padrão de formação de conflito na direção de transformá-lo, um dia, numa comunidade de segurança. Essas mudanças foram principalmente a reaproximação entre Brasil e Argentina e a formação do Mercosul, empreendimento capitaneado por essas duas potências regionais e dependente da convergência entre ambas.

\subsection{Opção pelo conceito de complexo de segurança regional para a América do} Sul

Na América do Sul, os temas tradicionalmente securitizados (definidos como ameaças existenciais à manutenção do status quo ou à sobrevivência dos atores) têm sido a economia e a política, como esclarecido acima.

A opção pelo conceito de complexo regional de segurança dá-se mediante o entendimento de que esses temas são os grandes desafios da América do Sul, acrescidos de novas ameaças (ilícitos transnacionais, migrações, proteção ambiental) que a TCSR, por conciliar perspectivas construtivistas e realistas/liberal-institucionalistas pode analisar com 
mais abrangência, e consistência, do que a teoria de comunidades de segurança, mesmo porque o pressuposto de uma comunidade de segurança foi derrubado pelas argumentações acima e o ponto de vista deste trabalho é de que a América do Sul, atualmente, ainda encaminha seu processo de construção de uma comunidade identitária, etapa necessária à conformação de uma eventual comunidade de segurança.

Mesmo na condição de complexo de segurança, as instituições da América do Sul ainda não têm suficiente poder de enforcement e sua abrangência é limitada, sendo mais visível nos temas de economia e comércio, como demonstram os principais empreendimentos regionais, a Comunidade Andina e o Mercosul. Porém, o que se percebe é uma intenção em alargar o escopo de tais instituições para temas sociais, políticos, ambientais, militares etc. $\mathrm{O}$ ensaio econômico-comercial é o mais visível porque há a perspectiva de que é necessária uma resposta imediata às rápidas transformações da globalização internacional, como demonstram os processos de regionalização via formação de blocos econômicos em outras partes do mundo.

A avaliação dos conceitos de comunidade de segurança e complexo de segurança regional deste trabalho conclui que a América do Sul configura um complexo de segurança regional, não uma comunidade de segurança, e isto porque este último conceito não sobrevive às circunstâncias atuais da América do Sul, tendo sido verificados conflitos recentes envolvendo forças militares e verificando-se que, mesmo onde tais conflitos não existem, a latência de ressentimentos por conflitos históricos instabiliza a região ou, caso tais ressentimentos não sejam fortes, a institucionalização da segurança e o grau de confiança mútua ainda não adquiriram o grau suficiente para que se acredite na conformação de uma comunidade de segurança.

O mais próximo que a leitura da autora permitiu aproximá-la da argumentação construtivista de Adler e Barnett (1998) e Hurrell (1998) foi concluir que a América do Sul, no Cone Sul, estaria mais próxima (comparativamente ao Entorno Andino/Amazônico) da configuração de uma comunidade de segurança que, amadurecida, provavelmente configuraria uma comunidade de segurança pluralista e frouxa, enquanto, no Entorno Andino, graças a fatores de conflitos latentes e instabilidades internas com potencial de spillover, terse-ia um subcomplexo de segurança andino, como definem Buzan et al. (2003).

Este trabalho, assim, tentar conciliar as visões de Adler e Barnett, por um lado, que verificam a emergência de uma comunidade de segurança no Cone Sul, mas não no Entorno 
Andino, com, por outro lado, a visão de Buzan et al., de que a América do Sul compõe dois subcomplexos regionais de segurança, definidos pelo Cone Sul e pelo Entorno Andino, estando aquele mais próximo da conformação de uma comunidade de segurança, embora esse estágio ainda esteja longe de ser alcançado.

Os principais motivos para que a autora faça esta opção estão em que as políticas cooperativas dos governos sul-americanos, principalmente no que diz respeito à cooperação militar, estão num estágio inicial que precede à formação das comunidades de segurança, mas não necessariamente leva a elas. Qual seja esse estágio: a coordenação das políticas de segurança motivada pelos fatores precipitadores migrações e pirataria (sobretudo no Cone Sul) e narcotráfico e biopirataria (acentuados no Entorno Andino/Amazônico). Esse estágio corresponde ao primeiro grupo de elementos que Adler e Barnett identificaram para seu enquadramento analítico de emergência de comunidades de segurança.

As outras duas cadeias de fatores que levam à uma comunidade de segurança, sobre as quais se discorreu no primeiro capítulo deste trabalho (p. 18), elementos estruturaisprocessuais e elementos identitários, também se verificam na América do Sul, mas não apontam para o desenvolvimento de uma comunidade de segurança porque, apesar de se apresentarem há muito tempo em iniciativas para o fortalecimento das instituições subregionais e em práticas discursivas de mitigação das divergências de identidade, sofrem constantes estagnação e retrocesso, o que dificulta a visualização de uma comunidade de segurança emergente. 
PARTE II - OS SUBCOMPLEXOS DE SEGURANÇA TRADICIONAIS NA AMÉRICA DO SUL 


\section{CAPÍTULO 3 - O SUBCOMPLEXO DO CONE SUL}

\subsection{Mercosul - o principal empreendimento cooperativo no Cone Sul}

\subsubsection{Uma união aduaneira e zona de livre comércio}

O Cone Sul tem um histórico cooperativo mais tradicional do que o do subcomplexo andino, remontando ao Tratado de Consulta e Amizade entre Brasil, Argentina e Chile, escrito pelo Barão do Rio Branco no início do século XX, mas que não foi ratificado devido às divergências entre Brasil e Argentina e à desconfiança mútua entre esses dois países.

A partir da década de 1940, com o peronismo na Argentina e o varguismo no Brasil, as duas potências regionais da América do Sul vivenciaram uma reaproximação que duraria até o período Quadros, como os encontros de Uruguaiana, e seria interrompida no período militar, salvo pelas coordenações militares expressas sobretudo pela Operação Condor. A cooperação institucional de longo prazo não seria proeminente nesse período, se comparada às iniciativas de a partir do fim da década de 1980, com a saída dos militares do poder.

Os padrões atuais da configuração cooperativa no Cone Sul herdam o espírito dos Acordos de Uruguaiana, que levam Brasil e Argentina ao entendimento de que sua aproximação deve ter uma perspectiva de longa duração, e não condicionada às opções políticas temporárias de governos individuais.

Na definição do principal empreendimento integrador para o continente, o Mercosul, a partir das conversações entre Sarney e Alfonsín em fins da década de 1980, duas temáticas de segurança permeariam a construção da nova instituição: a segurança econômica e a segurança política.

No que diz respeito à segurança econômica, o Mercosul deveria atuar favorecendo a inserção das economias de seus Estados-membro (Brasil, Argentina, Paraguai e Uruguai) e Estados-parte (Bolívia e Chile) num mundo globalizado e competitivo: "El MERCOSUR no fue creado como una fortaleza con vocación de aislamiento; por el contrario, fue concebido como un reaseguro de la inserción de nuestros países al mundo exterior. "22

\footnotetext{
${ }^{22}$ Ver http://www.mercosur.int/msweb/portal\%20intermediario/es/index.htm. Acesso em 09/06/2008.
} 
No que diz respeito à segurança política, havia a necessidade de consolidar as instituições democráticas que confeririam credibilidade e previsibilidade aos novos governos sul-americanos após o fim das ditaduras militares. Buzan e Wæver afirmam: "It was not solid democracies that generated peace. It was the potential loss of democracy that motivated security measures" (2003, p. 325). O Protocolo de Ushuaia, assinado em julho de 1998 por Brasil, Argentina, Paraguai, Uruguai, Bolívia e Chile, no âmbito do Mercosul, é um dispositivo em que os países reconhecem que "la vigencia de las instituciones democráticas es condición indispensable para la existencia y desarrollo de los procesos de integración y que toda alteración del orden democrático constituye un obstáculo inaceptable para la continuidad del proceso de integración regional"23.

A securitização de temas sob o Mercosul não se expressa em uma lista de ameaças definidas, mas a manutenção da instituição serve como baluarte de afastamento de quaisquer instabilidades mais graves na região. O Mercosul se manifesta como uma "aliança estratégica" que, apesar do progresso atravancado e muitas vezes estagnado tenta ser, ao menos, a garantia de que a cooperação regional não regresse aos níveis anteriores à década de 1990.

O Mercosul foi criado em março de 1991 pelo Tratado de Assunção, firmado entre Argentina, Brasil, Paraguai e Uruguai. O objetivo fundamental desse tratado era a integração dos quatro Estados por meio da livre circulação de bens, serviços e meios de produção; o estabelecimento de uma tarifa alfandegária e uma política comercial comuns; a coordenação de políticas macroeconômicas e setoriais, bem como a harmonização das legislações nas áreas pertinentes, a fim de fortalecer o processo de integração ${ }^{24}$.

Em 1994, foi firmado o Protocolo de Ouro Preto, que estabeleceu a estrutura institucional do Mercosul e lhe conferiu personalidade jurídica internacional. A partir de Ouro Preto, deu-se início ao período de implementação e aprofundamento dos instrumentos da zona de livre comércio e união aduaneira, que vigoram sob a Tarifa Alfandegária Comum. Pretende-se que a zona de livre comércio e a união aduaneira sejam etapas intermediárias até o Mercado Comum, que é entendido segundo a lógica neoliberal de que o crescimento comum advirá do efeito multiplicador da especialização e das economias de escala.

\footnotetext{
23 Ver também o Protocolo de Ushuaia, disponível em http://www.mercosur.int/msweb/portal \%20intermediario/es/index.htm. Acesso em 08/06/2008.

${ }^{24}$ Ver http://www.mercosur.int/msweb/portal\%20intermediario/es/index.htm. Acesso em 09/06/2008.
} 
A perspectiva neoliberal para uma instituição multilateral (ou plurilateral, dada a diferença nos pesos decisórios dos diferentes países, com Argentina e Brasil ocupando os papéis protagônicos) na América do Sul é uma novidade. O empreendimento anterior, a ALALC, fracassaria pela dificuldade em conciliar abertura econômica e protecionismo, enquanto, apesar das falhas, o Mercosul tenta absorver a lógica da abertura comercial para aumentar a competitividade e os investimentos estrangeiros, esperando estar amparado por um maior poder negociador internacional em virtude da atuação em bloco.

Espera-se que os agentes internacionais vejam numa instituição com o propósito de conciliar as políticas comerciais de seus membros um parceiro comercial mais previsível e confiável. Internamente, espera-se que a integração gere um nível de interdependência que supere os interesses conflitivos, a serem conciliados num novo espaço político comum e paralelo, embora não independente, aos aparatos nacionais. Esse espaço político é o espaço das políticas elaboradas e implementadas no âmbito do próprio Mercosul.

No ano 2000, iniciou-se uma nova etapa no processo de integração, intitulada Relançamento do Mercosul. O objetivo dessa nova etapa foi reforçar a união aduaneira internamente e também com seus parceiros internacionais. Para o alcance desse objetivo, as medidas a serem implementadas são a adoção de políticas fiscais e monetárias para garantir os pagamentos e a estabilidade dos preços. Entre os temas prioritários dessa etapa estavam a ampliação do acesso a mercados (tanto entre os componentes do Mercosul quanto dos parceiros externos), a otimização dos trâmites de fronteira e o incentivo à formação de zonas francas. Ainda nessa etapa, foi assinado, em fevereiro de 2002, o Protocolo de Olivos para a Solução de Controvérsias, que entrou em vigor em 2004.

Em julho de 2006, os países do Mercosul assinaram o Protocolo de Adesão da Venezuela ao bloco. Nesse documento estão previstos os prazos para que cada um dos quatro membros alcance o livre comércio com o novo país, bem como este se compromete, dentro de prazos específicos para cada uma das demais partes, a liberalizar seu comércio ${ }^{25}$.

\subsubsection{Mercosul - além do comércio e da economia}

A opção por centralizar a análise do subcomplexo de segurança no Cone Sul exclusivamente num panorama do Mercosul é justificável porque essa instituição é o

\footnotetext{
${ }^{25}$ Ver Protocolo de Adhesión de La Rep. Bolivariana de Venezuela al Mercosur. Disponível em http://www.mercosur.int/msweb/portal\%20intermediario/es/index.htm. Acesso em 08/06/2008.
} 
empreendimento integrador mais bem-sucedido na região, embora sua eficiência ainda não tenha alcançado o que suas propostas almejam.

O Mercosul abriga em vários de seus documentos, como atas de reuniões, declarações presidenciais, mecanismos que superam os arranjos concebidos para as áreas de comércio e economia, abrangendo posições dos membros acerca de temas como segurança, cultura e sociedade. A instituição é, assim, um objeto adequado para a análise da aplicação dos conceitos de complexo de segurança e comunidade de segurança/identitária apresentados neste trabalho.

No concernente à segurança além da esfera econômica, os quatro Estados-membro e os dois Estados-parte, Bolívia e Chile, constituíram, em junho de 1997, o Mecanismo de Consulta e Concertação Política, estabelecendo posições comuns em matérias que superam o estritamente econômico e comercial. O objetivo desse Mecanismo, segundo seu parágrafo $1^{\circ}$ é: “articular, en el ámbito de sus propósitos, las acciones necesarias para ampliar y sistematizar la cooperación política entre las Partes, entendida como aquella cooperación referida a todos los campos que no formen parte de la agenda económica y comercial de la integración" ${ }^{26}$. Dentro da esfera de segurança política, anteriormente, em junho de 1996, fora firmada a Declaração Presidencial sobre Compromisso Democrático no Mercosul, cujo entendimento era de que a plena vigência das instituições democráticas era condição indispensável para a existência e desenvolvimento do Mercosul.

Na mesma ocasião de assinatura da Declaração de 1996, os seis países do Mercosul subscreveram uma Declaração que reafirmava o apoio do Mercosul aos direitos legítimos da Argentina na disputa pela soberania sobre as Ilhas Malvinas. A Declaração, portanto, apresentou uma dimensão securitizadora sob dois aspectos: securitizou a democracia e definiu um "inimigo" externo comum, ao afirmar que os países sul-americanos do Mercosul convergem com a Argentina na questão das Malvinas e, necessariamente, discordam da soberania britânica sobre as ilhas. Essa definição implícita de inimigo, porém, além de estar restrita a um assunto pontual (soberania) dá-se mais no nível retórico e formal do que prático, não sendo válido inferir que os países sul-americanos comporiam uma aliança militar com a Argentina numa hipotética tentativa de retomada das ilhas.

\footnotetext{
${ }^{26}$ Declaración Presidencial sobre la Consulta y Concertación Política de los Estados Partes Del Mercosur. Disponível em http://www.mercosursalud.org/espanhol/mercosul/historico/MCCP.htm. Acesso em 09/06/2008.
} 
A segurança militar sob o Mercosul está mais explícita na Declaração Política do Mercosul, Bolívia e Chile como Zona de Paz, assinada na mesma ocasião em que foi aprovado o Protocolo de Ushuaia, em 1998. Por meio dessa Declaração, os signatários atestam que a paz constitui um elemento essencial para a continuidade e desenvolvimento da integração regional. Entre os outros pontos, foi acordado, nesse documento, fortalecer os mecanismos de consulta e cooperação sobre temas de segurança e defesa, bem como promover uma articulação progressiva e realizar esforços conjuntos, nos foros pertinentes, para avançar-se na consolidação de acordos internacionais voltados para o desarmamento nuclear e a não-proliferação de armas atômicas.

As temáticas securitizantes sob o Mercosul dão-se sobre as bases de uma pressuposta comunidade identitária, cujos princípios são os de confiança, harmonia, razoabilidade e previsibilidade, que deve ser fortalecida e cuja expressão está na comunhão de valores expressa em "sociedades democráticas, pluralistas, defensoras das liberdades fundamentais, dos direitos humanos, da proteção ao meio ambiente, do desenvolvimento sustentável, comprometidas com a consolidação das democracias e da segurança jurídica, com o combate à pobreza e com o desenvolvimento socioeconômico igualitário"27.

O Mercosul desempenha suas funções numa perspectiva de integração de longo prazo. Ele tem o propósito de consolidar uma percepção de identidade comum entre os países sulamericanos e, até o alcance dessa percepção, pretende ser o garante da estabilidade e coesão da região: "El MERCOSUR es un elemento de estabilidad en la región, pues el entramado de intereses y relaciones que genera, profundiza los vínculos tanto económicos como políticos y neutraliza las tendencias hacia la fragmentación" ${ }^{28}$.

\subsection{Brasil - hegemonia estabilizadora?}

O papel diferenciado do Brasil no Cone Sul pode ser entendido segundo um destes três conceitos, hegemonia, preponderância ou liderança, um deles descrevendo melhor as condições do país segundo a época analisada na história de sua política externa, bem como segundo as percepções dos outros países do continente sul-americano acerca do papel do Brasil no mesmo período ${ }^{29}$.

\footnotetext{
${ }^{27}$ Ver http://www.mercosur.int/msweb/portal\%20intermediario/es/index.htm. Acesso em 09/06/2008.

${ }^{28}$ Idem.

${ }^{29}$ Galvão (2003), pp. 122-9. Ver também BANDEIRA, Luiz Alberto Moniz (1998): O expansionismo brasileiro e a formação dos Estados na Bacia do Prata. $3^{\text {a }}$ Ed. Rio de Janeiro: Revan, Brasília: UnB.
} 
O conceito de hegemonia é de "existência de certos atributos de poder que fornecem a um Estado a capacidade de se sobrepor a outros em um determinado sistema ou sociedade de Estados" (Galvão, 2003, p. 123). Os principais atributos de poder seriam população, território, recursos naturais, vigor econômico, força militar e estabilidade política, e que naturalmente vêm se modificando ao longo da história em sua abrangência e aplicação. Trata-se, portanto, de uma soma entre hard e soft power.

O conceito de preponderância aplica-se quando um Estado, mesmo dispondo da soma dos elementos que definem sua categorização como hegemônico, utiliza-se parcialmente de tais recursos, sem, assim, poder ser considerado hegemônico, mas apenas preponderante.

Por último, o conceito de liderança conjuga três fatores: a percepção externa dos outros Estados; a autodisposição de se colocar como líder e a capacidade de liderar, que inclui condições históricas e materiais. A liderança, ainda, pressupõe legitimidade, ou seja, consentimento por parte dos outros Estados do grupo envolvido. A legitimidade, por sua vez, não se exerce apenas por meio de ameaças e incentivos, mas também por meio de um processo de “"sociabilização' e transformação dos sistemas de crenças e valores dos estados secundários, que tem a função de estabelecer metas e ordenar referências" (Galvão, 2003, p. 124).

Admitindo-se que o Brasil tenha desempenhado alternadamente os papéis de hegemon, ator preponderante ou líder, é possível considerar-se também que as estratégias de cooperação no continente tenham sido, em vários momentos, como no Pacto $\mathrm{ABC}$ de Rio Branco e na OPA de Kubitschek, capitaneadas por ele, a quem também pode se atribuir, em grande medida, os fracassos, estagnações e retrocessos de tais empreendimentos. Um período de baixa autonomia na política externa brasileira, como o período de 1954-1958, citado anteriormente, também correspondeu a pouca iniciativa de coordenação, cooperação e integração regional. Ao peso do Brasil ainda deve ser adicionado o peso de outros atores relevantes no sistema sul-americano, como a Argentina e o Chile, dotados dos recursos de hard e soft power em proporções muito semelhantes às do Brasil em determinados períodos históricos e se comparados estes três atores aos demais países da América do Sul.

Mesmo com o relativo equilíbrio de capacidades entre Argentina, Brasil e Chile, sobretudo a partir da década de 1960, com o crescimento econômico acelerado nos três países, isolar o Brasil para verificar como suas condições internas e encaminhamento de política externa determinam as condições de estabilidade na região tem sido uma estratégia freqüente 
na literatura (Buzan e Wæver, 2003, pp. 324-8; Hurrell, 1998, pp. 260-4). Aqui será seguida essa tendência, a fim de que se faça uma breve análise de como o Brasil assumiu seu papel na América do Sul e colaborou para a coesão do continente, gerando condições favoráveis à cooperação e à integração.

Durante o período Rio Branco, 1902-1912, o Brasil era percebido por seus vizinhos como hegemônico: possuía o maior território, a maior população, grande concentração de recursos naturais estratégicos e era o parceiro preferencial dos Estados Unidos na América do Sul. Apesar dessa percepção externa, o país, segundo Bueno e Cervo (apud Galvão 2003, p. 123):

\begin{abstract}
nunca haveria alimentado pretensões hegemônicas na América do Sul durante o período Rio Branco. Contudo, a questão a ser apreciada vai além da simples ação efetiva do Brasil, apontando para a perpetuação de uma visão de mundo, que passaria a afetar as chancelarias sul-americanas com relação a possíveis pretensões hegemônicas do Brasil"30.
\end{abstract}

No período Rio Branco, a memória das guerras Cisplatina e do Paraguai era recente. O país, portanto, tinha um histórico de uso da força para a definição de suas fronteiras, a questão mais problemática na conformação dos países recém-independentes. $\mathrm{O}$ país ainda compunha o centro das principais alianças militares do continente sul-americano no século XIX e, dentro da escala de poder na América do Sul, poderia ser mesmo considerado o hegemon. Bandeira (1998, p. 103), para justificar esse argumento, cita Gramsci: “a grande potência, cuja força militar sintetiza o valor da sua extensão territorial e do seu potencial econômico é 'hegemônica, chefe e guia de um sistema de alianças e acordos com maior ou menor extensão"”.

Mesmo assim, um empreendimento marcante no período Rio Branco foi a primeira tentativa de concerto entre Brasil, Argentina e Chile expressa no Tratado de Cordial Amizade de 1909. Segundo Bueno (2003, pp. 182-220), não se incluía entre os objetivos brasileiros relativos à vertente atlântico-plantina, naquela época, a pretensão à hegemonia, mas sim uma influência compartilhada com a Argentina e, num grau menor, com o Chile. A presença de Zeballos, como mencionado anteriormente, foi um impeditivo para o sucesso do concerto.

Deve ser admitido, porém, que as percepções dos vizinhos sul-americanos não eram completamente incompatíveis com a forma como os formuladores da política externa

\footnotetext{
${ }^{30}$ Galvão, 2003, p. 123, grifo no original. Galvão retirou sua referência a Bueno e Cervo do Seminário Novas Visões Acerca do Brasil durante a República Velha. Brasília, 15 de maio de 2003, FA, UnB.
} 
brasileira percebiam seu país. Para comprovar que no Brasil se percebia a presença de fatores materiais que o destacavam entre seus vizinhos, pode ser citado o próprio Barão do Rio Branco:

Desinteressando-se das rivalidades estéreis dos países sul-americanos, entretendo com esses Estados uma cordial simpatia, o Brasil entrou resolutamente na esfera das grandes amizades internacionais, a que tem direito pela aspiração de sua cultura, pelo prestígio de sua grandeza territorial e pela força de sua população ${ }^{31}$.

O que pode ser concluído, do período Rio Branco, é que havia um equilíbrio entre a forma como o Brasil pretendia se apresentar a seus vizinhos (um país generoso e cordial, interessado em dirimir as suspeitas acerca de sua origem lusitana singular), a forma como o Brasil via a si mesmo (isso ocultado no discurso de política externa) e a forma como seus vizinhos o percebiam (com pretensões hegemônicas).

No período Vargas, um momento importante na forma como o Brasil atuou frente a seus vizinhos foi a mediação brasileira na Guerra do Chaco. Bueno e Cervo (2002, p. 244) afirmam que as chancelarias hispano-americanas reagiam diferentemente quando o Brasil estava envolvido nas negociações de paz entre Bolívia e Paraguai, que resultavam infrutíferas enquanto este país tentava se manter afastado da questão, e que só se chegou a um acordo quando o Brasil abandonou sua posição de neutralidade:

Em 23 de maio de 1933, Getúlio Vargas decretou a observância da completa neutralidade durante a guerra entre os dois países vizinhos, iniciada no ano anterior. Todavia, depois de várias - mais exatamente 18 - tentativas fracassadas de mediação [...], o Brasil, na hora certa e seguro do seu êxito, exerceu o papel de mediador no conflito, juntamente com outros países americanos, especialmente com a Argentina. [...]

Em 12 de junho de 1935, esgotadas as duas nações [Bolívia e Paraguai] e depois de intenso e árduo trabalho de mediação, no qual se destacaram Macedo Soares [chanceler brasileiro] e Saavedra Lamas [chanceler argentino], foi assinado em Buenos Aires [...] o "Protocolo sobre a Convocação da Conferência da Paz, relativa ao Conflito do Chaco", pelo qual cessava o conflito armado. (Bueno e Cervo, 2002, pp. 244-245, grifos da autora.)

Na questão do Chaco, o peso da Argentina também deve ser levado em consideração, pois sua presença também pode ser considerada uma variável relevante à resolução do conflito, além de poder atuar como exemplo da constatação da hipótese deste trabalho, a de

\footnotetext{
${ }^{31}$ Telegrama para Washington, 22/11/1909, apud Viana Filho,1959, p. 393.
} 
que o eixo Brasil e Argentina, ou Brasil, Argentina e Chile, é o centro dirigente de grande parte das soluções para os principais problemas sul-americanos.

Após o período Vargas, o período Dutra é comumente referido na historiografia como uma fase de alinhamento automático (Bueno e Cervo, 2002, p. 269) prolongado ao "hiato Café Filho" (Bueno e Cervo, 2002, p. 284) e interrompido, pelo menos no discurso, pelos governos Juscelino Kubitschek e Quadros, este com sua Política Externa Independente (Bueno e Cervo, 2002, p. 290, para o período JK e pp. 309-312, para o período Quadros).

O período militar (1964-1985) foi uma ruptura dos empreendimentos autonomistas dos dois governos precedentes, onde se tentou estabelecer uma "correção de rumos" (Bueno e Cervo, 2002, p. 367).

Durante o período militar, afora a coordenação técnica sob a Operação Condor, houve uma competição de hegemonia com a Argentina, o que inviabilizou o status hegemônico do Brasil na época (Galvão, 2003, pp. 127-8).

Atualmente, o Brasil ocupa uma situação de preponderância (utilização parcial de seus recursos de soft e hard power), mas tem evoluído para um cenário de liderança, principalmente dada a percepção externa de seus vizinhos e de outros atores internacionais de seu papel diferenciado dentro do continente sul-americano. Essa tendência de tornar-se um líder, segundo Galvão, que analisa a construção de uma identidade sul-americana por meio de métodos como a análise do discurso, vem se evidenciando a partir da I Reunião de Presidentes da América do Sul de 2000 (Galvão, 2003, p. 129).

Para alcançar a condição de líder, o Brasil tem adotado novas estratégias de imposição no sistema sul-americano. A integração regional parte em redes de interação econômicocomerciais que consideram o peso do Brasil ou mesmo redes em que ele é o centro, já que, atualmente, o país é a maior economia do continente sul-americano ${ }^{32}$. Outra estratégia tem sido a de tomar frente aos principais debates internacionais e apresentar-se como arauto não apenas da América do Sul, mas de todo o grupo dos países em desenvolvimento, como foi o caso da quebra das patentes de medicamentos. Na área ambiental, graças a possuir em seu território a maior parte da Amazônia, o Brasil é um ator cujas movimentações internacionais são acompanhadas de perto, exigindo-se dele políticas mais eficientes de combate ao desmatamento ilegal e preservação da biodiversidade, bem como coerência entre sua política

\footnotetext{
32 BBC Brasil.com, 14/03/2008: "Problemas internos limitam o poder regional do Brasil". Disponível em http://www.bbc.co.uk/portuguese/reporterbbc/story/2008/03/080310_amsbrasilabredb.shtml. Acesso em 20/06/2008. A matéria cita que a economia brasileira é a maior do continente sul-americano, tendo, em 2007, exportado US\$ 31 bi para seus vizinhos e importado deles US\$ 18,5 bi.
} 
de defesa do biocombustível e a aliança com países que crescem às custas de energia suja (China e Índia), o que tem retardado a implementação dos regimes de controle internacional da mudança climática.

No âmbito do Mercosul, a questão ambiental é tratada dentro do Acordo-Quadro sobre Meio Ambiente do Mercosul, assinado em junho de 2001 em Assunção e aprovado pelo Congresso Nacional brasileiro em julho de $2003^{33}$. As principais disposições desse documento são: “instrumentalizar a aplicação dos princípios da Declaração do Rio de Janeiro sobre Meio Ambiente e Desenvolvimento, de 1992, que não tenham sido objeto de tratados internacionais" (Art. $2^{\circ}$ ); proteger o meio ambiente e utilizar os recursos naturais de forma mais eficiente, pautando a atuação das Partes pelos princípios de "gradualidade, flexibilidade e equilíbrio" (Art. $3^{\circ}$, alínea $a$ ); concatenar uma sinergia entre a atuação dos governos e da sociedade civil na defesa ambiental (este propósito perpassa vários artigos do texto, como o Art. $3^{\circ}$, alínea $e$ e o Art. $6^{\circ}$ ).

\section{CAPÍTULO 4 - O SUBCOMPLEXO ANDINO}

\subsection{O Pacto Andino ou Comunidade Andina}

\footnotetext{
${ }^{33} \mathrm{O}$ decreto presidencial que coloca em vigor o Acordo-Quadro é o Decreto $\mathrm{N}^{\mathrm{o}} 5.528$, de 17/09/2004, disponível em http://www2.mre.gov.br/dai/mercosul_3534.htm. Acesso em 20/06/2008. Anexado ao Decreto está o texto do AcordoQuadro.
} 
O Pacto Andino (ou Grupo Andino que, desde 1997, recebe a denominação de Comunidade Andina) foi firmado em 1969 entre Colômbia, Equador, Peru, Bolívia e Chile pelo Acordo de Cartagena (Acordo de Integração Sub-Regional Andino), que estabelecia um bloco comercial entre esses países, ao qual se uniu, em 1973, a Venezuela e do qual se retirou o Chile em 1976. A Venezuela também se retirou em 2006, portanto o Pacto/ Comunidade, atualmente, possui apenas quatro membros. O Grupo Andino fora criado com o propósito de servir de contrapeso ao predomínio do grupo ABRAMEX (Argentina, Brasil e México) no processo de negociação da ALALC (Galvão, 2003, p. 102).

Com a nova percepção de alargamento das temáticas de segurança para além dos tradicionais temas político-militares, um bloco comercial é indicador de que vários países resolvem se unir para se fortalecerem frente a duas tendências do sistema internacional atual: a de globalização e a de regionalização. Existe, entre os países na atualidade, o entendimento de que as negociações entre blocos têm mais chance de êxito do que negociações país a país, daí o interesse em definir associações baseadas em fatores como similaridade de situação econômica e identidade cultural, critérios que tendem a coincidir com a proximidade geográfica definidora do conceito objetivo de região ${ }^{34}$.

O propósito de formar um bloco para aumentar o poder de barganha com países exógenos vem expresso na alínea $a$ do Artigo $3^{\circ}$ do Acordo de Cartagena ${ }^{35}$, ou seja, prevê-se, na alínea, que, para alcançarem-se os objetivos do Acordo, sejam aprofundados a integração com os demais blocos econômicos regionais e o relacionamento com esquemas extraregionais nos âmbitos político, social e econômico-comercial. O Protocolo de Sucre, que

\footnotetext{
${ }^{34}$ Por conceito objetivo de região, quero dizer região com base no território, conforme definida por Buzan e Wæver (2003, p. 48), que não ignoram o discurso e a prática dos atores na definição do conceito de região, mas alertam que região, por ser um conceito, precisa ser um instrumento analítico, e não apenas "um elemento discursivo veiculado pelos atores" (Herz, s/d, p. 9). Acerca dos conceitos de região, regionalismo e regionalização ver Monica Herz (s/d, p. 8). Região seria "o espaço social onde processos diferenciados se desenvolvem"; regionalismo, "um fenômeno em que ocorre a coordenação de políticas por parte dos atores envolvidos" e, por último, regionalização referir-se-ia a um "processo de intensificação das relações a nível regional, que pode ocorrer antes do desenvolvimento do regionalismo ou depois, podendo ainda ocorrer na esfera econômica, de segurança ou cultural". Acerca da dimensão subjetivista de regionalismo, ver Adler (1997). Para este autor, o regionalismo ocorre quando os atores adotam essa definição e região é definida pelos significados atribuídos pelos atores envolvidos no processo de regionalização ou em um projeto regionalista. $\mathrm{Na}$ definição de região segundo Adler são centrais a identidade, os costumes e as práticas dos atores.

${ }^{35}$ A versão consultada do Acordo não é a original de 1969, pois já exclui o Chile e inclui a Venezuela entre os países-membro. Trata-se, aqui, da versão elaborada em 1997 pelos Presidentes dos paísesmembro e que transformou o Pacto Andino em Comunidade Andina. O texto está disponível em http://www.comunidadandina.org/normativa/tratprot/acuerdo.htm. Acesso em 22/5/2008.
} 
altera o Acordo, é mais detalhado a esse respeito, pois acrescenta ao Capítulo II do Acordo o Capítulo "Relações Externas", com novos artigos definidores das atividades a serem implementadas pelos Ministros das Relações Exteriores dos países-membro e pela Comissão da Comunidade Andina no sentido de aumentar a interação do bloco com outros organismos multilaterais. Textualmente:

\footnotetext{
Artículo .- Para el logro del objetivo enunciado en el presente Capítulo, el Consejo Andino de Ministros de Relaciones Exteriores y la Comisión de la Comunidad Andina emplearán, entre otras, las medidas siguientes:

a) Fortalecer la participación comunitaria en foros económicos y comerciales, internacionales, multilaterales, hemisféricos y regionales;

b) Coordinar negociaciones conjuntas de la Comunidad Andina con otros procesos de integración o con terceros países o grupos de paises; $y$,

c) Encomendar investigaciones, estudios y acciones a la Secretaría General que permitan alcanzar el objetivo y las medidas previstos en el presente Capítulo. ${ }^{136}$
}

Além disso, o processo de regionalização pela via da integração comercial tem configurado uma tentativa de garantir a segurança a partir da liberalização dos fluxos comerciais, o que, pretende-se, aumenta a interdependência entre os países e o bem-estar social de suas populações, consolida as democracias e reduz os conflitos internos e entre Estados.

O que pode ser considerada uma fonte latente de conflito na região é o enclausuramento boliviano, pois o país não possui uma saída para o mar e isso é considerado um grande entrave ao desenvolvimento de sua economia, que depende de concessões de outros territórios para o escoamento de suas importações e exportações. No Artigo $4^{\mathrm{o}}$ do Acordo, os países-membro se comprometem em "procurar soluciones adecuadas que permitan resolver los problemas derivados del enclaustramiento geográfico de Bolivia."

Os dispositivos do Acordo de Cartagena não são formulados em termos de segurança, mas percebe-se que têm o cuidado de manifestar a atenção do Pacto/ Comunidade sobre tópicos freqüentemente securitizados ou securitizáveis. Ainda no Artigo $3^{\circ}$, após as alíneas que normatizam as medidas econômico-comerciais que devem viabilizar o bloco, vêm as alíneas que prevêem medidas como ações no campo da integração fronteiriça (a segunda alínea $b$ ) e ações para o aproveitamento e conservação dos recursos naturais e do meio ambiente (a segunda alínea $d$ ).

\footnotetext{
${ }^{36}$ Disponível em http://www.comunidadandina.org/normativa/tratprot/sucre.htm. Acesso em 22/5/2008.
} 
Tanto as questões de fronteira quanto a preservação ambiental têm escalado na agenda de prioridades de segurança. O vácuo de poder nas fronteiras da América do Sul foi causa das guerras de fronteira no continente, dada a dificuldade de se afirmar a qual Estado um território pertencia e, atualmente, esse vácuo representa uma ameaça aos Estados por tornar-se um foco de atividades transnacionais ilícitas. Quanto à questão ambiental, um tema proeminente na atualidade é a preservação da floresta amazônica e se a presença maior de ONGs do que do Estado é positiva ou negativa, gerando riscos de atuação de um transnacionalismo nocivo.

Para a Comunidade Andina, o aquecimento global é outro tema de importância, pois o degelo andino tem aumentado e seus efeitos conjuntos ao desmatamento amazônico podem trazer impactos globais de mudança climática. A Agenda Ambiental Andina prevê os impactos econômicos dessa mudança climática para a Comunidade Andina: prevê que, em 2025, os prejuízos advindos dessa mudança cheguem a $\$ 30$ bi anuais (média das moedas locais), o que corresponde a 4,5\% do PIB atual da Comunidade, isso sem contar as perdas econômicas que levam em consideração a redução de biodiversidade, geração hidrelétrica e abastecimento de água ${ }^{37}$. A possibilidade de aumento das incidências do El Niño agravam as estimativas.

A escolha do termo comunidade para designar o grupo andino sintoniza-se com a concepção de que há uma história comum e um compartilhamento de identidades e interesses, como define Adler (1997), mas não se aplica ao conceito de comunidade de segurança porque não se chegou ao ponto, definidor do conceito, em que a possibilidade de conflito entre os países se torna mínima a ponto de poder ser descartada nos cálculos de segurança e percepção de ameaça entre os Estados. Vale ressalvar, porém, que as ameaças que impedem a definição de uma comunidade de segurança nos Andes não dizem respeito a ameaças Estado-a-Estado, o que decorre, em grande medida, das baixas capacidades militares dos países da região, e não da ausência de ressentimentos em relação às guerras do passado. As principais ameaças desestabilizadoras da região decorrem do potencial de spillover das convulsões domésticas nesses países.

\subsubsection{Colômbia - foco do spill-over de tensões na região}

\footnotetext{
37 "Climate Change Knows no Boundaries - Impact of Climate Change in the Andean Community" In Andean Environmental Agenda. Disponível em http://www.comunidadandina.org/ingles/desarrollo/libro_climate_change.htm. Acesso em 22/5/2008.
} 
O subcomplexo andino definido por Buzan e Wæver compreende os países do entorno ocidental-setentrional da América do Sul: Equador, Colômbia, Venezuela, Peru e Bolívia (Buzan e Wæver 2003, p. 333).

Os conflitos da região, seguindo a natureza da maior parte dos conflitos do continente sul-americano, referem-se, sobretudo, a questões de fronteira, como explicitado no capítulo anterior. O principal conflito, na última década, foi o conflito entre Peru e Equador em 1995 e temas de segurança relacionados ao narcotráfico, sobretudo na Colômbia, têm sido relevantes para a análise deste subcomplexo que, comparado ao subcomplexo do Cone Sul, vivencia dinâmicas que o distanciam da consolidação de uma comunidade de segurança. Buzan e Wæver (2003, p. 327) chegam a comentar que a situação colombiana, como a boliviana, está, atualmente, mais próxima da situação do século XIX: grandes parcelas de poder concentradas nas mãos dos caudillos, os "coronéis" da América hispânica, que detêm grande autoridade sobre territórios e homens armados a seu serviço.

Outra questão passível de análise para a dificuldade no alcance do estágio de comunidade de segurança está em que as democracias dos países andinos foram constantemente abaladas ao longo da década de $1990^{38}$.

A Colômbia, apontada pela literatura levantada para este trabalho como o país mais problemático da região que Buzan e Wæver (2003) denominam subcomplexo andino de segurança (outras categorizações podem ser feitas, como entorno amazônico, mas essa é uma discussão teórica de proposição de uma nova unidade de análise que este trabalho, devido a seu porte, não pretende aprofundar), tem, em sua situação doméstica, uma importante fonte para o entendimento da instabilidade na região, pois os conflitos que esse país vivencia têm tido efeito de spillover nos países vizinhos e mesmo aumentado a atenção internacional para a região.

A violência colombiana é uma guerra travada entre quatro partes: guerrilhas de viés esquerdista (embora as FARC, principais representantes da categoria grupos guerrilheiros, recebam dos governos colombiano e norte-americano o rótulo de grupos terroristas com um propósito político degenerado e apenas retórico ${ }^{39}$ ), cartéis de drogas, grupos paramilitares de direita e o Estado. A descrição do caso colombiano ainda tem o agravante de não ser mais

\footnotetext{
${ }^{38}$ Acerca da democracia na América do Sul nos anos 1990, ver: Journal of Democracy 12 (2).(2001).

39 Após o 11 de setembro, os Estados Unidos redefiniram sua atuação na Colômbia declarando abertamente que atuam contra grupos terroristas e a favor do Estado colombiano. Ver SERAFINO, Nina; STORRS, K. Larry (2002): Andean Regional Iniatitive (ARI): FY 2002 Supplemental and FY 2003 Assistance for Colombia and Neighbors, Washington, DC: Congressional Research Service, CRS Report for Congress, RL 31383.
} 
possível delimitar essas quatro partes tradicionais, visto que as três primeiras partes encontram-se intimamente imbricadas e seus interesses já não são mais claramente distintos. Buzan (2003, p. 328) reporta que essa imbricação entre os três primeiros grupos deve-se ao envolvimento com ganhos advindos da produção e comercialização de drogas, o que cria uma categoria híbrida de narcoguerrilla e tem resultado num enfraquecimento do Estado e na privatização da violência.

O Plano Colômbia, projeto de auxílio financeiro e logístico norte-americano para o combate ao narcotráfico na região andino-amazônica, iniciado na década de 1990, gera dúvidas teóricas quanto ao papel dos Estados Unidos na região: tratar-se-ia de uma penetração ou de um overlay da grande potência hemisférica (e global) nos assuntos desse subcomplexo?

Como esclarecido anteriormente, penetração e overlay são conceitos formulados por Buzan e Wæver (2003) para indicar o grau em que uma grande potência se imiscui nos assuntos de segurança de outra região. Penetração é um grau de envolvimento inferior ao de overlay, pois, neste último caso, o hegemon regional/global estende suas preocupações regionais de segurança a uma região distinta da sua a tal ponto que formula e implementa instituições de segurança comum. Ilustração de overlay foi a criação da OTAN no início da Guerra Fria, pois os Estados Unidos ampliaram sua agenda de segurança para incluir a Europa. Levantar a hipótese de o Plano Colômbia ser um exemplo de overlay pressupõe que o Plano é um tipo de instituição.

Ainda dentro das preocupações teóricas, vale ressaltar que as principais críticas ao Plano Colômbia, numa época em as questões de segurança apresentam um alargamento para além das temáticas político-militares, referem-se a seu foco militarista e de combate às drogas sob uma perspectiva que ignora o usuário (o componente social que poderia ser securitizado), pois as iniciativas empreendidas sob o Plano são, principalmente, de aprimoramento das forças militares (concessão de armamentos e reestruturação logística).

Um resultado perigoso desse tipo de iniciativa tem sido a autonomia da lógica militar em detrimento de outras dinâmicas sociais, o que pode comprometer ainda mais a estabilidade da região. Essa preocupação é freqüentemente reportada pelos governos vizinhos, temerosos de sua segurança e da necessidade de adotarem uma agenda de segurança proeminentemente militarista. Além disso, o Plano Colômbia é enviesado no sentido de combater apenas as guerrilhas que se declaram ou são consideradas esquerdistas, ignorando os paramilitares de direita que também desestabilizam o Estado colombiano. 
Buzan e Wæver (2003) também questionam se, a partir do 11 de setembro, não seria o caso de se pensar a atuação norte-americana na América do Sul via Colômbia como uma redefinição de atuação interregional para atuação global, pois agora tratar-se-ia de uma das frentes na ampla "guerra contra o terrorismo", não mais apenas uma guerra contra as drogas, de foco interregional ou hemisférico.

Os próprios autores respondem a seu questionamento afirmando tratar-se de atuação regional, não global, pois a atuação norte-americana não estaria integrada sob a forma de uma "guerra coerente" (Buzan e Wæver, 2003, p. 328) de tal modo que indicasse uma estrutura sistêmica: trata-se mais de uma nova rotulagem e de uma forma de legitimar a condução da guerra contra as drogas como uma operação de contra-insurgência. As guerrilhas colombianas, lembram os autores, vincularam-se ao IRA e a temáticas marxistas, mas não aos movimentos islâmicos do Oriente Médio a que os Estados Unidos se reportam como sendo os alvos de sua guerra contra o terror.

Bolívia e Peru completam o quadro da instabilidade cujo foco é a Colômbia primariamente porque os principais campos para o cultivo de coca encontram-se em seus territórios, enquanto, na Colômbia, estão as refinarias de cocaína e os barões do tráfico (estes também domiciliados no México e mesmo no Brasil, onde, com grande repercussão midiática, foi preso recentemente o traficante foragido Juán Carlos Abadía).

A estratégia de "ponte aérea" norte-americana foi eficiente em interceptar grandes quantidades de coca produzidas na Bolívia e Peru antes de sua chegada à Colômbia, de modo que as produções nesses dois primeiros países vêm decresceram entre 1995 e 1998, retomando o crescimento a partir de $2001^{40}$.

Os efeitos colaterais dessa estratégia, contudo, têm sido o aumento da produção colombiana e a centralização, em seu território, da cadeia produtiva que se inicia no plantio e se encerra no refino e distribuição. A estratégia de redução no número de focos de combate à droga para um país, em vez de três, longe de tornar o combate ao narcotráfico uma tarefa mais fácil, tem demonstrado, em grande medida, fracassos, pois não era prevista a capacidade de reestruturação da rede de narcotráfico num território em que o governo está enfraquecido para combater as forças paramilitares que se mantêm com os ganhos da droga. Além disso, a

\footnotetext{
${ }^{40}$ A produção peruana caiu 56\% desde 1995, segundo a Strategic-Survey 1999-2000:86, apud Buzan e Wæver, 2003, p. 329. Na Colômbia, por outro lado, o cultivo de coca aumentou 25\% em 2001 (Serafino e Storrs, 2002, op. cit., p. 9).
} 
concentração da produção em um território aumenta os preços e a atividade se torna mais atraente.

A estratégia do governo colombiano para o enfrentamento da situação foi, durante muitos anos, uma atuação em frente dupla: por um lado, permitir, entre 1998 e 2002, a atuação das FARC e do ELN numa zona desmilitarizada do tamanho do Estado Suíço e, por outro, elaborar um plano ambicioso de combate a guerrilhas que contaria com amplo suporte financeiro e logístico norte-americano.

Em 2000, os Estados Unidos liberaram US\$ 1,3 bi dos US\$ 7,5 bi do Plano Colômbia. A política norte-americana chegou a incluir concessões financeiras aos países vizinhos da Colômbia. Desde 2001, essa atuação norte-americana tem se balizado na Iniciativa Regional Andina, cujo orçamento solicitado para 2003 foi de US\$ 1 bi, dos quais mais da metade seriam destinados à Colômbia, enquanto o restante seria alocado, em ordem decrescente, para Peru, Bolívia, Equador, Brasil, Panamá e Venezuela. (Buzan e Wæver, 2003, p. 329).

A crise colombiana se espalha para seus vizinhos na América do Sul e agrava um problema que não pode mais ser definido como crise doméstica ou ineficiência estatal. O Peru e, sobretudo, o Equador importam a instabilidade do negócio da coca, dado que possuem regiões de fronteira com a Colômbia em pontos cruciais de atuação das guerrilhas de narcotráfico.

Além de Peru e Equador, a instabilidade atinge a Bolívia, "o elo mais fraco da cadeia" (Buzan e Wæver, 2003, p.330), com seus cocaleros bem organizados politicamente e sua percepção de que a proibição do cultivo de coca é mais um efeito nocivo da globalização na região ${ }^{41}$. A atuação desse grupo, representado politicamente em partidos bolivianos, tem sido a de securitizar os esforços anti-narcóticos em termos de ameaça econômica e à sua identidade, pois os elementos de respeito à cultura indígena têm ganhado força e sido incorporados ao discurso político do reordenamento social boliviano desde meados do século $\mathrm{XX}$.

O subcomplexo andino, a despeito do reordenamento militar de Peru e Equador em relação à Colômbia, ainda assim não deve ser entendido como tendo, em sua dinâmica central, a ameaça de Estado a Estado e, por outro lado, também não deve ser considerado um locus onde as ameaças estão totalmente desterritorializadas. Buzan e Wæver, como afirma

\footnotetext{
${ }^{41}$ Ver GENTLEMAN, Judith A. (2001): The Regional Security Crisis in the Andes: Patterns of State Response, Carlisle, PA: US Army College, Strategic Studies Institute, pp. 6-7 e 23-5.
} 
Schleicher (s/d, p. 5), admitem que seu conceito perca o viés geográfico, dadas as dinâmicas de transnacionalidade das relações internacionais atuais.

The Andean subcomplex is not easily understood in terms of state-to-state security relations, but the complicated 'transregional' security dynamics that tie together domestic and international (intermestic) issues do not produce total deterritorialisation. They tie together at a relatively consistent Andean subregional level. (Buzan e Wæver, 2003, p. 331).

\subsection{Organização para o Tratado de Cooperação Amazônica (OTCA) - proposição} de uma nova unidade de análise para o entorno andino-amazônico?

A discussão sobre se uma nova unidade de análise em substituição à de subcomplexo andino de segurança seria mais adequada ao estudo da dinâmica do entorno amazônico e enquadra-se na discussão maior sobre os novos temas securitizados, que Buzan, Wæver e de Wilde iniciaram em seu trabalho de 1998.

Criar um subcomplexo amazônico pode se apresentar como um empreendimento acadêmico adequado à análise dos novos temas de segurança na América do Sul e não exclui as categorizações tradicionais, mesmo porque a TCSR de Buzan e Wæver (2003) prevê que um país possa integrar simultaneamente mais de um subcomplexo.

Assim como a análise dos subcomplexos andino e do Cone Sul focou-se nas principais instituições da região, sem questionar sua eficácia, mas apenas para abrir um leque analítico cujo vértice fosse uma entidade representativa, onde interações e debates relevantes ocorrem, poderia ser proposta a análise de um novo subcomplexo, o amazônico, a partir da Organização do Tratado de Cooperação Amazônica (OTCA), que poderia tornar-se, dado seu foco de atuação concentrado na Amazônia, a principal instituição governamental multilateral (organização internacional) a tratar dos problemas da região. Porém, o que se observa é seu insucesso, seu caráter decorativo, decorrente da falta de delegação, por parte dos governos, de um papel mais definido e efetivo para o órgão.

O Tratado de Cooperação Amazônica foi firmado em 3 de julho de 1978 entre Bolívia, Brasil, Colômbia, Equador, Guiana, Peru, Suriname e Venezuela "com o objetivo de promover ações conjuntas para o desenvolvimento harmônico da Bacia Amazônica"42. A OTCA foi criada em 1995 e, em 2002, sua Secretaria Permanente estabeleceu-se em Brasília.

\footnotetext{
42 Organização do Tratado de Cooperação Amazônica. http://www.otca.org.br/br/organizacao/index.php?id=98. Acesso em 10/06/2008.
} 
A Organização pretende basear-se no princípio do desenvolvimento sustentável da Amazônia e atua sobretudo em fóruns internacionais divulgando a necessidade de proteger-se o patrimônio natural amazônico. Entre os dias 19 e 29 de maio de 2008, a OTCA participou da Nona Conferência das Partes do Convênio Sobre Diversidade Biológica (CoP 9- CDB) “em atividades paralelas onde divulgou o biocomércio e o turismo em áreas protegidas"43.

Apesar de originar-se de um Tratado de três décadas, a Organização não tem sido expressiva na aglutinação dos temas amazônicos, aparecendo como inexpressiva frente às principais instituições governamentais regionais, o Mercosul e a Comunidade Andina, no enfrentamento dos problemas da região amazônica. A maior parte de sua documentação divulgada refere-se a encontros com instâncias dessas organizações, bem como refere-se à participação em eventos internacionais do porte da CoP 9, mas sem uma voz audível, e sim "paralela".

A OTCA manifesta-se pressionando organizações maiores a reiterarem compromissos com os acordos ambientais internacionais de proteção à biodiversidade da região e sua concentração na retórica, em detrimento da prática, é semelhante à questão ambiental na década de 1970, quando os países, em suas reuniões multilaterais, esforçavam-se em consolidar os princípios do Direito Internacional Ambiental e não obtinham de suas conversações resultados mais palpáveis, embora não se deva dizer que essas conversações foram infrutíferas, pelo contrário, elas foram necessárias para balizar as decisões e ações futuras na área de meio ambiente.

A fraqueza da OTCA não é um demérito da própria instituição, mas um resultado da falta de delegação de atividades e de poder de enforcement por parte de seus países-membro, que preferem deliberar e agir com mais eficácia no âmbito das organizações regionais mais tradicionais, das quais a maior parte deles também faz parte.

A baixa representatividade e eficiência quase nula da OTCA não invalidam, porém, um esforço de definição de uma nova unidade de análise, um subcomplexo amazônico, para o estudo dos novos temas de segurança na região. O que poderia ser feito seria encontrar um novo centro, substitutivo à OTCA, para esse subcomplexo, talvez até mesmo fora das bases institucionais ou territoriais de um Estado, o que desafiaria o conceito de região em bases territoriais no qual se define a TCSR.

\footnotetext{
${ }^{43}$ Idem.
} 
O centro irradiador da securitização na Amazônia, se não seus Estados, poderiam ser a comunidade internacional, bem como as redes transnacionais interessadas na preservação ambiental ou no vazio de poder e vigilância dos Estados contra práticas ilegais na região.

Diferentemente do ocorrido no Mercosul e na Comunidade Andina, que firmaram-se como foco de grande parte dos debates sub-regionais, esta organização pode não se configurar como um centro irradiador de securitizações da biopirataria, narcotráfico, migrações, desmatamento e outros ilícitos transnacionais.

Como alternativa a uma instituição formal atuando como centro da dinâmica de regionalização amazônica, podem ser verificados atores não-estatais cuja atuação preenche o vazio dos Estados e, inclusive, favorece-se dessa ausência. Exemplos de tais atores e atuação são as redes de narcotráfico do complexo coca-cocaína, atuantes na bacia amazônica ocidental, que deixam evidências da lavagem de dinheiro na região em índices como a alta taxa de cheques compensados em áreas pouco povoadas e geram o que muitos autores reportam como um desenvolvimento econômico alternativo na região, ou seja, um desenvolvimento de fontes ilegais, mas efeitos sociais que, em alguns aspectos, podem ser considerados benéficos, por exemplo, com a inserção das pequenas famílias de agricultores no plantio da coca e com a melhoria da infra-estrutura regional graças à lavagem do dinheiro do tráfico $^{44}$.

\section{CONCLUSÃO}

\footnotetext{
${ }^{44}$ Ver, a respeito das movimentações financeiras e do desenvolvimento amazônicos vinculado ao tráfico, MACHADO, Lia Osório (2003): "Movimento de Dinheiro e Tráfico de Drogas na Amazônia". Discussion Paper Series $N^{o} 22$. In Management of Social Transformation I (1994-2003)/ UNESCO. Disponível em: http://www.unesco.org/most/ds22por.htm\#note2. Acesso em 20/06/2008.
} 
Os conceitos de comunidade de segurança e complexo regional de segurança pretendem, a partir de pressupostos teórico-metodológicos distintos, explicar a ausência de conflitos numa região e entender que padrões cooperativos os atores desenvolvem com o fim de evitarem que o choque de interesses comprometa a estabilidade regional.

Para a análise da América do Sul, a autora optou por adaptar tais conceitos, trazendo de cada um deles a contribuição que julgou mais relevante para a compreensão do continente.

Acerca do conceito de comunidade de segurança, concluiu-se aqui que ele não é aplicável ao caso sul-americano, pois a condição para a existência desse tipo de comunidade, a ausência de conflitos militares, não é observada na região como um todo, apenas em loci separados, como o Cone Sul, embora o conceito de comunidade de segurança seja talvez de difícil operacionalização por não especificar por quanto tempo é necessário não haver ameaça Estado-Estado até que se confirme a existência desse tipo de comunidade.

Por outro lado, observam-se, nos empreendimentos cooperativos, o interesse em consolidá-los sobre o argumento de uma identidade comum, a sul-americana. Assim, a autora realizou uma fusão entre o conceito de comunidade e uma das dimensões que a compõem (o compartilhamento de valores e identidades), ou seja, a dimensão identitária, para formar o conceito heurístico comunidade identitária, aplicável à América do Sul dentro do panorama, traçado do período Rio Branco ao atual, de cooperação e percepção do outro dentro do continente.

O conceito de complexo de segurança regional teve um aproveitamento maior neste trabalho, graças à sua elasticidade para compreender as diversas esferas da interação entre Estados numa região: desde os tradicionais temas político-militares até as dimensões mais subjetivas da afirmação de identidade e sua proteção (segurança societal).

A componente liberal-institucionalista da TCSR esteve clara na escolha por analisar os subcomplexos da América do Sul a partir das principais organizações regionais multilaterais, cujo objetivo é maximizar os resultados das interações entre os atores, além de lhes conferir previsibilidade e transparência. A contribuição neo-realista manifestou-se com clareza no pressuposto de que os países são diferentes na distribuição de poder na região, havendo uma assimetria persistente entre o eixo $\mathrm{ABC}$ e os demais países. A alteração da polaridade regional condiciona-se ao crescimento econômico e à estabilidade política, que também determinam os rumos e ritmos da cooperação. 
Por último, dentro da TCSR, foi proposta uma nova unidade de análise, o subcomplexo amazônico, cuja criação vem ao encontro da necessidade de definir com mais precisão, dentro do complexo de segurança regional sul-americano, o locus dos novos desafios/ameaças de segurança para a região, aqueles cuja fonte não opera dentro das bases de um Estado e torna-os ainda mais difícil de serem administrados porque atuam onde há vazio de vigilância e mesmo indefinição de jurisdição estatal.

O esforço empreendido neste trabalho foi o de lapidar uma lente de análise da América do Sul que pudesse aproveitar tanto os recursos da vertente construtivista em que se baseia o conceito de comunidade de segurança, quanto os recursos (estes de origem mais diversificada, tanto construtivista quanto realista e liberal-institucionalista) fundamentais ao conceito de complexo regional de segurança.

Este foi um exercício despretensioso e cheio de lacunas, cujo objetivo foi valorizar a herança de abordagens aparentemente incomunicáveis, mas cuja soma pode ser a melhor forma de compreender várias das dinâmicas conjunturais e estruturais da América do Sul. 
ACORDO-QUADRO SOBRE MEIO AMBIENTE DO MERCOSUL. http://www2.mre.gov.br/dai/mercosul_3534.htm. Acesso em 20/06/2008.

ACUERDO DE CARTAGENA. http://www.comunidadandina.org/normativa/tratprot/acuerdo.htm. Acesso em $22 / 5 / 2008$.

ADLER, Emmanuel (1997): Imagined Security Communities: Cognitive Regions in International Relations. Millennium, 26.

ADLER, Emmanuel; BARNETT, Michael (1998): Security Communities. Cambridge, Cambridge University Press.

ANDEAN

ENVIRONMENTAL

AGENDA. http://www.comunidadandina.org/ingles/desarrollo/libro climate change.htm. Acesso em $22 / 5 / 2008$.

ATKINS, G. Pope (1999): Latin America and the Caribbean in the International System. $4^{\text {th }}$ Edition, Boulder, CO, and Oxford: Westview Press.

BANDEIRA, Luiz Alberto Moniz (1998): O expansionismo brasileiro e a formação dos Estados na Bacia do Prata. $3^{\text {a }}$ Ed. Rio de Janeiro: Revan, Brasília: UnB.

BUENO, Clodoaldo (2003): Política Externa da Primeira República: os anos de apogeu (1902-1918). São Paulo: Paz e Terra, 2003.

BUENO, Clodoaldo; CERVO, Amado (2002): História da Política Exterior do Brasil. Brasília: Editora UnB.

BUZAN, Barry (1983): Peoples, States and Fear. Brighton: Wheatsheaf.

BUZAN, Barry; LITTLE, Richard (2000): International Systems in World History. Oxford: Oxford University Press.

BUZAN, Barry; WÆVER, Ole (2003): Regions and Powers - The Structure of International Security. Cambridge Studies in International Relations: 91. Cambridge: Cambridge University Press.

BUZAN, Barry; WÆVER, Ole; De WILDE, Jaap (1998): Security - a New Framework for Analysis. London, Colorado-US: Lynne Rienner Publishers, Boulder.

CUTLER, Claire A. (1991). "The 'Grotian Tradition' in International Relations". Review of International Studies 17 (1): 41-65.

DECLARACIÓN PRESIDENCIAL SOBRE LA CONSULTA Y CONCERTACIÓN POLÍTICA DE LOS ESTADOS PARTES DEL MERCOSUR. http://www.mercosursalud.org/espanhol/mercosul/historico/MCCP.htm. Acesso em 09/06/2008.

DEUTSCH, Karl. Political community and the North Atlantic Area. Princeton University Press. Princeton, 1957. 
FLEMES, Daniel (2005): "Notas teóricas sobre a formação de uma comunidade de segurança entre a Argentina, o Brasil e o Chile". Rev. Sociol. Polit., Jun 2005, no.24, p.217-231. Também disponível em http://www.scielo.br/pdf/rsocp/n24/a14n24.pdf. Acesso em 01/06/2008.

GALVÃO, Thiago Gehre (2003): América do Sul: a Construção de uma idéia. Dissertação para a obtenção do grau de Mestre em Relações Internacionais. Brasília: Universidade de Brasília.

HERZ, Monica (s/d): "Regionalismo e Segurança Regional: perspectivas analíticas". Documento de trabalho $\mathrm{n}^{\circ}$ 4. Projeto Líderes Regionais e Segurança Internacional Brasil, África do Sul e Índia. Brasília: UnB-Instituto de Relações Internacionais, Ford Foundation.

HURRELL, Andrew (1998): "An emerging security community in South America?" In ADLER, E.; BARNETT, Michael. Security Communities... (op. cit). Pp. 228-264.

KACOWICZ, Arie M. (1998): Zones of Peace in the Third World: South America and West Africa in Comparative Perspective, New York: State University of New York Press.

KRATOCHWIL, Friedrich. (1989) Rules, Norms and Decisions. Cambridge: Cambridge University Press.

MARCELLA, Gabriel; SCHULZ, Donald E. (1999): "War and Peace in Colombia", Washington Quaterly 22 (3): 213-28.

MERCOSUR. http://www.mercosur.int/msweb/portal\%20intermediario/es/index.htm. Acesso em 08/06/2008.

NYE Jr., Joseph (2003): "Is There an Enduring Logic of Conflict in World Politics?" in NYE Jr., Joseph. Understanding International Conflicts - an Introduction to Theory and History. Chapter 1. $4^{\text {th }}$ Edition. Longman, p. 2.

(2002): O paradoxo do poder americano. São Paulo: Editora Unesp, p. 30.

ORGANIZAÇÃO DO TRATADO DE COOPERAÇÃO AMAZÔNICA. http://www.otca.org.br/br/organizacao/index.php?id=98. Acesso em 10/06/2008.

PROTOCOLO DE ADHESIÓN DE LA REP. BOLIVARIANA DE VENEZUELA AL MERCOSUR. $\quad$ http://www.mercosur.int/msweb/portal \%20intermediario/es/index.htm. Acesso em 08/06/2008.

PROTOCOLO DE USHUAIA. http://www.mercosur.int/msweb/portal \%20intermediario/es/index.htm. Acesso em 08/06/2008. Acesso em 08/06/2008.

PROTOCOLO

$\mathrm{DE}$

SUCRE. http://www.comunidadandina.org/normativa/tratprot/sucre.htm. Acesso em 22/5/2008.

SCHLEICHER, Rafael. "O Papel dos Líderes Regionais na Segurança Internacional: uma Revisão Teórico-Conceitual”. Documento de trabalho $\mathrm{n}^{\mathrm{o}}$ 8. Projeto Líderes 
Regionais e Segurança Internacional - Brasil, África do Sul e Índia. UnB-Instituto de Relações Internacionais, Ford Foundation. Brasília, s/d.

VAZ, Alcides Costa (2002). Cooperação, Integração e Processo Negociador: a Construção do Mercosul. Brasília: IBRI.

VIANA FILHO, Luiz (1959): A vida do Barão do Rio Branco. Rio de Janeiro: José Olympio.

WÆVER, Ole (1989). "Conflicts of Vision - Visions of Conflict” In WÆVER et al. Pp. 283-325.

WATSON, Adam. (1992) The Evolution of the International Society. London: Routledge.

WENDT, Alexander (1999). Social Theory of International Politics. Cambridge: Cambridge University Press. 